\title{
KARIŲ KAPAI VILNIUJE, RASTI ARCHEOLOGINIŲ TYRIMŲ METU
}

\author{
Dr. Kęstutis Katalynas \\ Lietuvos nacionalinis muziejus \\ Dr. Manvydas Vitkūnas \\ Generolo Jono Žemaičio Lietuvos karo akademija
}

\section{IVADAS}

Vilnius per savo ilgaamžę istoriją ne kartą buvo tapęs kovų arena. XIV a. antroje pusejje jis buvo kelis kartus puolamas Vokiečių ordino ir jo sąjungininkų pajègų. $1655 \mathrm{~m}$. Lietuvos sostinè pirmą kartą buvo užimta svetimos valstybės kariuomenès. Iki $1661 \mathrm{~m}$. čia šeimininkavo maskvènai. 1702 m. Vilnių buvo užėmusi Švedijos kariuomenè. 1794 m. mieste, o $1831 \mathrm{~m}$. jo prieigose vyko dèl Lietuvos ir Lenkijos laisvès kovojusių sukilèlių mūšiai su Rusijos kariuomenès daliniais. $1812 \mathrm{~m}$. Vilnius tapo viena svarbiausių Napoleono Didžiosios armijos bazių ịsiveržimo ị Rusijos imperiją metu. 1863-1864 m. Vilniuje buvo vykdomos tuo metu vykusio sukilimo dalyvių egzekucijos. Pirmojo pasaulinio karo metais Vokietijos kariuomenè Vilnių užèmè be mūšio. 1918-1920 m. Vilnius kelis kartus ejo iš rankų i rankas - čia šeimininkavo Lietuvos, bolševikų, Lenkijos pajègos, mieste ir ypač jo prieigose vyko kovos. $1939 \mathrm{~m}$. Vilnius vèl priklausė Lietuvos valstybės jurisdikcijai, tačiau jau 1940 m. jame įsikūrè okupacinès Sovietų Sąungos kariuomenès daliniai. Antrojo pasaulinio karo pabaigoje Vilnius buvo gana smarkiai apgriautas, jo gatvèse vyko Raudonosios armijos ir Vermachto karių mūšiai.

Mūšių metu neišvengiamai žūdavo nemažai karių ir civilių. Dalies jų palaikai amžinojo poilsio atgulè miesto kapinèse, bažnyčių rūsiuose ir šventoriuose. Daugelis XX a. Vilniuje žuvusių, nuo sužeidimų, ligų, bado ir kitų priežasčių mirusių ịvairių tautybių karių yra palaidoti kapinèse (Antakalnio, Rasų, vokiečių karių kapinèse Vingio parke ir kt.). Tačiau 
Vilniaus mieste jau daugelį metų vykdant archeologinius tyrimus vis dar aptinkama ir iki šiol nežinomų pavienių karių ar jų grupių kapų, kartais ir masinių kapaviečių. Tik dalis tokių archeologų atradimų yra plačiau paviešinti. Daugeliu atvejų tyrejai apsiribojo savo atradimų aprašymu archeologinių tyrimų ataskaitose, o vienintele tokios informacijos skelbimo vieta tapo tęstinis mokslinis informacinis leidinys „Archeologiniai tyrinëjimai Lietuvoje“. Yra ir tokių atvejų, kai tyrimų duomenys lieka tik ataskaitose, o minètam leidiniui nebuvo parengta informacinių pranešimų, kai kurių tyrimų ataskaitų apskritai nèra. Todèl informacija apie archeologinių tyrimų metu aptiktus karių kapus gana padrika, fragmentiška, neretai sunkiai prieinama karo istorikams ir plačiajai visuomenei.

Iki šiol nebuvo bandymų kompleksiškai apžvelgti archeologinių tyrimų metu Vilniuje rastus karių kapus. Informacinę lentelę, kurioje pateikti lakoniški duomenys apie visus iki 2006 m. Vilniaus mieste archeologinių tyrimų metu rastus kapus, yra sudaręs archeologas Saulius Sarcevičius. Ši lentelè paskelbta Lietuvos istorijos instituto Miestų tyrimo skyriaus sudarytame „Vilniaus archeologijos atlase ${ }^{{ }^{\prime}}$.

Šio straipsnio autorių tikslas - pristatyti archeologinių tyrimų metu Vilniuje rastų karių kapų sąvadą, pateikiant pagrindinę informaciją apie šiuos kapus ir juose aptiktus radinius. Jame kartu pateikiama ir istorinė interpretacija, siejant juos su konkrečiais mieste vykusiais kovos veiksmais ar atskirų kariuomenès padalinių dislokacija. Rengiant sąvadą surinkta neskelbta informacija iš archeologinių tyrimų ataskaitų, saugomų Lietuvos istorijos instituto rankraštyne, Lietuvos nacionalinio muziejaus Viduramžių ir naujųų laikų archeologijos skyriaus archyve ir Nacionalinio muziejaus Lietuvos Didžiosios Kunigaikštystès Valdovų rūmų archyve. Taip pat buvo žodžiu apklausti archeologai, galeję turèti informacijos pasirinkta tema. Panaudoti tęstinio leidinio „Archeologiniai tyrinejjimai Lietuvoje“ moksliniai informaciniai straipsniai, spaudos publikacijos, peržiūrèti Lietuvos nacionaliniame muziejuje saugomi kai kurių tyrimų metu aptikti radiniai ${ }^{2}$.

1 Vilniaus m. archeologinių tyrimų metu aptiktų palaidojimų suvestinė // Vilniaus archeologijos atlasas [kompaktine plokštelè]. Sud. G. Vaitkevičius, O. Vailionienè. Vilnius, 2006. Interneto prieiga: http://www.istorija.lt/html/miestu.html [tikrinta 2012.11.15]

2 Šio sąvado autoriai už suteiktas konsultacijas nuoširdžiai dèkoja archeologams dr. Linui Girlevičiui, Daivai Luchtanienei, Sauliui Sarcevičiui, karo istorijos tyrinètojams Karoliui Mickevičiui, Sakalui Natkevičiui ir Gintautui Šironui. 
I sąvadą ịtrauktos tik tos kapavietès, kuriose palaidoti asmenys laikytini žuvusiais arba dèl įvairių kitų priežasčių mirusiais kariais, taip pat tos, kuriose pats laidojimo pobūdis (neiprastose vietose aptikti pavieniai kapai, iš bendro miesto kapinių konteksto išsiskiriančios netipinès kapavietės, kuriose palaidoti vien arba beveik vien vyrai), kapavietėse aptikti artefaktai (karių aprangos, uniformų detalès, ginklai), antropologinių tyrimų metu žmonių kauluose pastebėti koviniai (kirstiniai, šautiniai) sužalojimai leidžia palaidotus asmenis laikyti kariais. Sąvade nebandoma aptarti visų su karo veiksmais susijusių palaidotų žmonių - miestiečių, galimai žuvusių karo veiksmų metu, tokių kapų tyrimai yra galimo tolesnio darbo uždavinys.

Sąvade apžvelgiami kapai, datuojami XVII a. viduriu-XX a. viduriu. Duomenų apie ankstesnio laikotarpio kapus, kuriuos galima būtų neabejotinai priskirti kariams, ligšioliniai archeologiniai tyrimai nesuteikia. Tačiau labai tikètina, kad ateityje gali būti aptikta ir viduramžių laikotarpio karių kapų, juolab kelias XIII-XV a. datuojamas Vilniaus miestiečių laidojimo vietas (kapinynus Bokšto, Latako gatvèse ir kt.) archeologams pavyko rasti.

Sąvade nèra apžvelgiama viena išskirtinè, archeologų ištirta (tyrimų grupès vadovas - Vytautas Urbanavičius) laidojimo vieta - sovietų represinių struktūrų aukų kapavietė Tuskulènų dvarvietėje, kurioje 1944-1947 m. buvo slapta užkasti NKGB (MGB) vidaus kalejjime nužudyti žmonès. Daug nužudytų ir šioje kapavietejje užkastų asmenų buvo kariai (Lietuvos partizanai - pasipriešinimo sovietiniam režimui dalyviai, Armijos Krajovos (AK) partizanai, dezertyravimu apkaltinti Raudonosios armijos kariai, vokiečių karo belaisviai ir kt.). Tačiau atsižvelgiant i tai, kad ši kapavietè, kurios vietoje yra ịkurtas Tuskulėnų rimties parko memorialinis kompleksas, gerai žinoma, o jos tyrimų dalis duomenų paskelbta ${ }^{3}$, šiame straipsnyje apie Tuskulènų kapavietę nebus kalbama.

\footnotetext{
3 Plačiausias istorinis masinès kapavietės Tuskulènuose tyrimas: Vaitiekus S. Tuskulènai: egzekucijų aukos ir budeliai (1944-1947). Vilnius, 2002; Archeologinių tyrimų informacija: Urbanavičius V. Grupinių kapų tyrimas Vilniuje, buv. Tuskulenų dvaro teritorijoje $2003 \mathrm{~m}$. Lietuvos istorijos instituto rankraštynas (toliau - LIIR), f. 1, b. 4152; Urbanavičius V., Vaškevičiūtė I. Tuskulènų dvaro likučių tyrinejjimai // Archeologiniai tyrinejjimai Lietuvoje 1996 ir 1997 metais. Vilnius, 1998, p. 328-330; Urbanavičius V. Grupinių kapų tyrimas Vilniuje, buvusio Tuskulènų dvaro teritorijoje // Archeologiniai tyrinejjimai Lietuvoje 2003 metais. Vilnius, 2005, p. 142-147.
} 
Kariu kapų radimvietės sugrupuotos teritoriniu principu pagal Vilniaus miesto dalis (Senamiestis, Lukiškès, Naujamiestis, Žvèrynas, Žvejai, Šnipiškès, Kareiviškès ${ }^{4}$, Rasos, Liepkalnis, Naujininkai, Paneriai).

I šș sąvadą taip pat pateko kai kurių karių palaikų ekshumacijų, atliktų Vilniaus miesto teritorijoje per paskutinius du dešimtmečius, duomenys. Jie iki šiol nèra susisteminti. Be abejo, ekshumacijos nèra tapačios archeologiniams tyrimams, nors jų metodika ir panaši. Tik kai kurios ekshumacijos atliekamos dalyvaujant archeologams ir fiksuojamos tyrimu ataskaitose.

Atsižvelgiant ị šio straipsnio pobūdị, autorių nuomone, būtų buvę netikslinga praleisti $\mathfrak{i}$ tyrèjų akiratị patekusius Vilniuje atliktų ekshumaciju duomenis, juolab kad jie gana svariai papildo žinias apie miesto teritorijoje rastus karių kapus.

Karių kapų ekshumacijos ir perlaidojimas Vilniuje vyko ịvairiais laikotarpiais. Ypač daug tokio pobūdžio darbų atlikta sovietmečiu, kai įvairiose miesto vietose aptikti Raudonosios armijos karių palaikai buvo perlaidojami Antakalnio karių kapinėse. Sovietmečiu rasti vokiečių karių palaikai dažniausiai dingdavo be žinios, veikiausiai vèl buvo užkasami atsitiktinèse, nuošaliose vietose ${ }^{5}$.

Karių palaikų ekshumacija vykdoma ir dabar, atkūrus Lietuvos nepriklausomybę. Šiuo metu vokiečių karių, palaidotų Lietuvos teritorijoje, palaikų ekshumacija ir perlaidojimu dažniausiai rūpinasi Vokiečiu karių kapų globos tautinè sąjunga (Vokietija) ir Všt Kultūros vertybių globos tarnyba (anksčiau - įmonė Karinio paveldo tyrimų kolegija), taip pat kai kurios kitos visuomeninès organizacijos. Beveik visa informacija apie karių palaikų ekshumacijas yra gauta iš vokiečių karių kapų paieška ir perlaidojimu besirūpinančios Všt Kultūros vertybiu globos tarnybos darbuotojo istoriko Sakalo Natkevičiaus.

\footnotetext{
4 Sovietmečiu šis kareivinių rajonas vadintas „Šiaurès miesteliu“. Tokiu pavadinimu ši Vilniaus miesto dalis (dabar jau demilitarizuota ir labai pasikeitusi) dažnai vadinama ir dabar. 5 S. Natkevičiaus žodinè informacija (2012 m. lapkričio 22 d.).

6 Vienas garsiausių ekshumacijos atvejų - 1993 m. Vilniuje, Savivaldybès aikštèje (dab. Vinco Kudirkos aikštè), atlikti SSRS kariuomenès generolo leitenanto Ivano Černiachovskio (1906-1945) palaikų ekshumavimo darbai. Palaikai buvo perlaidoti Maskvoje, Novodevičès kapinèse, o šalia kapo stovėjęs paminklas išvežtas ị Voronežą (Rusija). Šis garsus ekshumacijos atvejis šiame straipsnyje plačiau nebus aprašomas.
} 
Karių kapai Vilniuje, rasti archeologinių tyrimų metu

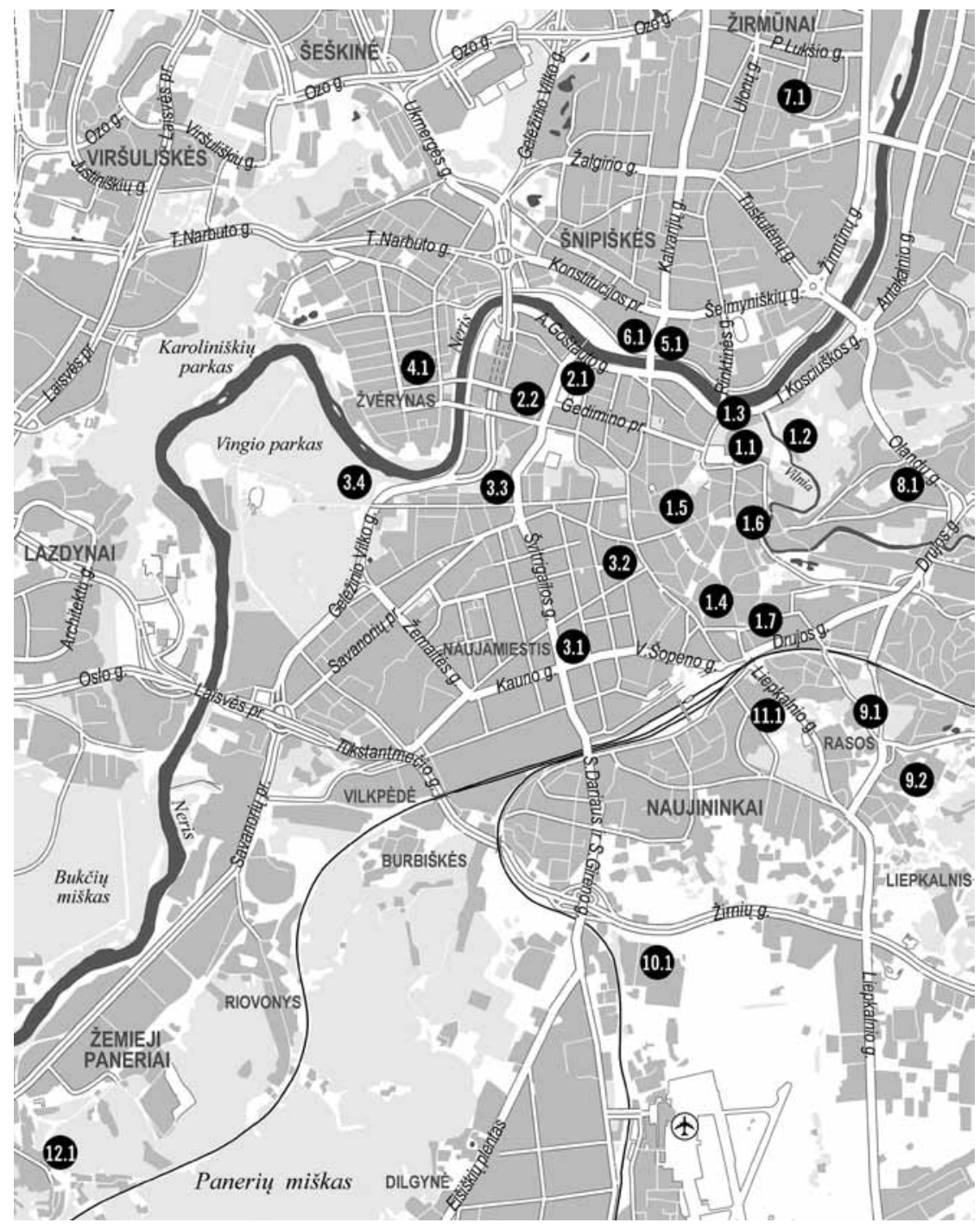




\section{ŽEMĖLAPIS}

\section{SENAMIESTIS}

1.1. Žemutinès pilies teritorija (Arsenalo g. 3). 1) 1863-1864 m. Lietuvos sukilèliu ar 1655-1661 m. okupacinès Rusijos kariuomenès karių kapai; 2) 1655-1661 m. Rusijos kariuomenès karių kapavieté; 3) su 1655-1661 m. ivykiais sietini kapai buv. Šv. Onos ir Barboros bažnyčios teritorijoje; 4) Antrojo pasaulinio karo SSRS ir Vokietijos karių kapavietès.

1.2. Kalnų parko teritorija. 1) 1655-1661 m. LDK karo su Rusija aukų kapai; 2) neaiški kapavietè.

1.3. Karaliaus Mindaugo tilto prieigos (Žygimantų, T. Vrublevskio ir Arsenalo g. sankirta). Antrojo pasaulinio karo SSRS karių kapavietė.

1.4. Bazilijonų vienuolyno kiemas (Aušros Vartų g. 7-Arklių g. 18). Antrojo pasaulinio karo Vokietijos karių kapavietè.

1.5. S. Moniuškos skveras (Šv. Ignoto g. 5). Antrojo pasaulinio karo Vokietijos karių kapavietè.

1.6. Latako ir Pilies g. kampas. Spejjama Pirmojo arba Antrojo pasaulinio karo Vokietijos karių kapavietè.

1.7. M. Daukšos g. 5. Antrojo pasaulinio karo Vokietijos karių kapavietė.

\section{LUKIŠKĖS}

2.1. Šv. Jokūbo ir Pilypo bažnyčios šventorius. Antrojo pasaulinio karo Vokietijos karių kapavietè.

2.2. Rotundo g. 4A. XIX a. Rusijos imperijos karių ir kitų asmenų kapavietè.

\section{NAUJAMIESTIS}

3.1. Kauno ir Švitrigailos g. sankirta. Spejjama masinè kapavietè.

3.2. Mindaugo g. $1831 \mathrm{~m}$. sukilimo laikų Rusijos karių kapavietè.

3.3. Z. Sierakausko g. 15. XIX a. Rusijos karių (?) ir kitų asmenų palaikų antrinio palaidojimo vieta.

3.4. Vingio parkas. Antrojo pasaulinio karo Vokietijos kario kapas.

\section{ŽVĖRYNAS}

4.1. Traidenio g. Antrojo pasaulinio karo Vokietijos karių kapavietè. 


\section{ŽVEJAI}

5.1. Žvejų g., Šv. Rapolo parapinès kapinès. Spejjamas AK kapitono Česlavo Grombčevskio kapas.

\section{ŠNIPIŠKĖS}

6.1. Kalvarijų g. pradžia (sunaikintas „Vilniaus kalnelis“). Spëjama 1812 m. karo Napoleono karių kapavietè.

\section{KAREIVIŠKĖS}

7.1. S. Žukausko g. 1812 m. karo Napoleono karių kapavietè.

\section{UŽUPIS}

8.1. Polocko g. ir Kreivojo skg. sankirta. Antrojo pasaulinio karo laikotarpio (?) kapas XVII a. kapinyno teritorijoje.

\section{RASOS}

9.1. Naujųjų Rasų kapinès. Antrojo pasaulinio karo SSRS karių ir kitų asmenų kapavietè.

9.2. Dunojaus g. 27. Antrojo pasaulinio karo Vokietijos karių kapavietè.

\section{LIEPKALNIS}

10.1. Žirnių g. Antrojo pasaulinio karo Vokietijos karių kapavietè.

\section{NAUJININKAI}

11.1. Tyzenhauzų g. 18A. Spejjama 1812 m. karo Napoleono karių kapavietè.

\section{PANERIAI}

12.1. Ūmẻdžių g. 16. $1812 \mathrm{~m}$. Napoleono kariuomenès karių arba $1831 \mathrm{~m}$. sukilimo dalyvių kapavietè. 


\section{SENAMIESTIS}

\section{1. Žemutinès pilies teritorija (Arsenalo g. 3)}

Vilniaus Žemutinès pilies teritorijos šiaurinèje dalyje, daugiausia pastatų Arsenalo g. 3 ir 3A (buvęs Senasis arsenalas, dabar - Lietuvos nacionalinio muziejaus dalis ir Taikomosios dailès muziejus) aplinkoje, rasta daug kapų, kuriuose aptikti palaikai priskirtini kariams.

1863-1864 m. Lietuvos sukilèlių ar 1655-1661 m. okupacinès Rusijos kariuomenès karių kapai? 1988 m. rekonstruojant pastato Arsenalo g. 3 (tuo metu - Vrublevskio g. 3) šiaurinị korpusą, greta jo buvo atliekami archeologiniai tyrimai (vadovas - Virginijus Raškauskas) ${ }^{7}$. Iš viso kasinètos keturios perkasos. Pastato kieme, perkasoje Nr. 4, 1,3-1,6 m gylyje aptikta 20 kapų ir dvi kaukolès iš suardytų kapų ${ }^{8}$. Antropologinių tyrimų duomenimis, devyneri palaikai buvo 25-40 m. vyrų; vienas iš dalies išlikęs skeletas galimai - moters. Dviejuose kapuose (Nr. 2 „bis“ ir Nr. 10) fiksuoti mirusiųjų patirti rankų kaulų lūžiai (sugiję). Kape Nr. 1

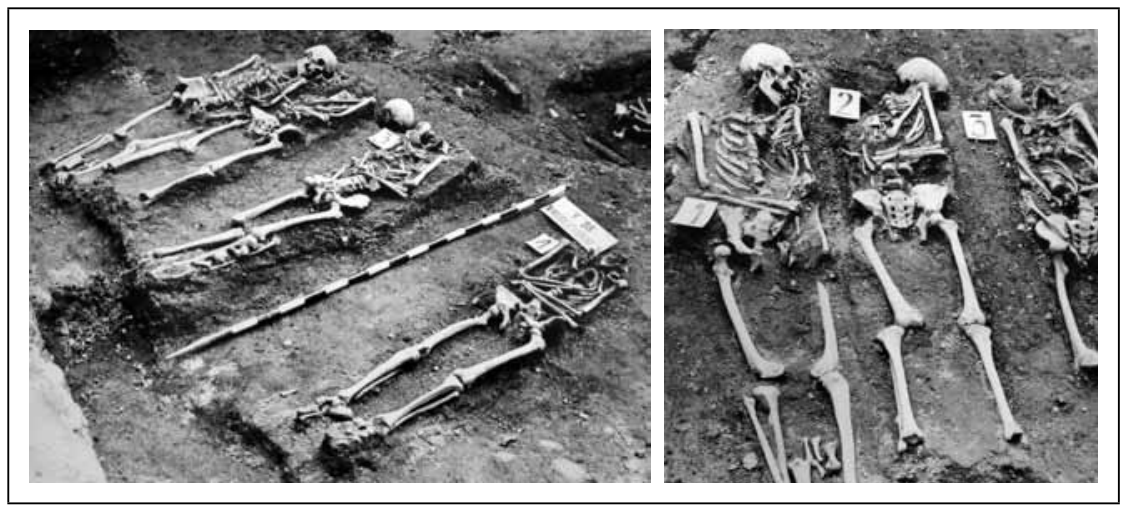

1-2 pav. Kapai, rasti archeologinių tyrimų metu Arsenalo g. 3 (tuo metu -

Vrublevsklio g. 3) 1988 m. Raškauskas V., 1988 m. archeologiniu tyrinèjimu Vilniuje, Vrublevskio g. 3, ataskaita. III dalis. LIIR, f. 1, b. 1610

7 Raškauskas V., 1988 m. archeologinių tyrinèjimų Vilniuje, Vrublevskio g. 3, ataskaita. I dalis. LIIR, f. 1, b. 1610.

8 Ataskaitos tekste nurodytas skirtingas aptiktų kapų skaičius: 18 (tekste) ir 20 (išvadose). Plg. Raškauskas V., 1988 m. archeologinių tyrinèjimų Vilniuje, Vrublevskio g. 3, ataskaita. I dalis. LIIR, f. 1, b. 1610, p. 24-37. 
palaidotas asmuo buvo patyręs galvos traumą ${ }^{9}$ Antropologai, sprendžiant iš ataskaitos, ištyre tik pirmuosius dešimt aptiktų skeletų.

Kapai Nr. 14, Nr. 15 ir Nr. 16, Nr. 17 buvo labai arti vienas kito, todèl padaryta išvada, kad jie gali būti vienalaikiai. Laidota karstuose, galvos orientuotos i pietvakarius arba ị vakarus. Kapų duobès ar perkasos kultūrinio sluoksnio pjūvyje neišsiskyrè. Kasant duobes kapams, apardytas XVI a. datuojamas sluoksnis. Virš kapų buvusiame, galimai permaišytame, horizonte aptikta XIX a. II puse datuotina plomba, todèl tyrimu vadovas V. Raškauskas padaré išvadą, kad laidota XIX a. ir kad galimai aptikti $1863 \mathrm{~m}$. sukilimo dalyvių palaikai ${ }^{10}$. Šia išvada, kurią V. Raškauskas pavadino „darbine“, t. y. negalutine, vèliau rèmèsi A. Vaicekauskas, datuodamas komplekso rytinèje dalyje aptiktus keturis kapus (žr. toliau). Iš tiesų pradinè hipotezè, esą tai sukilèlių palaikai, buvo iškelta aptikus pirmuosius dešimt kapų. Atidengus kitus kapus ir kasinèjimų medžiagą palyginus su istoriniais duomenimis, ji buvo paneigta dar $1988 \mathrm{~m}$. archeologinių tyrimų metu ${ }^{11}$. Konstatuota, kad aptiktų palaikų skaičius (vien tyrinètame plote 22 vnt.) nesutampa su realiai Lukiškèse 1863-1864 m. mirtimi nubaustų ir nežinomoje vietoje palaidotų sukilimo lyderių skaičiumi (iš viso nužudytas 21 asmuo). $1864 \mathrm{~m}$. gegužès $22-28 \mathrm{~d}$. Lukiškèse mirties bausmé buvo skirta 21 sukilèliui: 12 sušaudyti ir 9 pakarti $^{12}$, o kapavieteje rasti 23 palaikai (20 išlikusių skeletų ir 2 pavienès kaukolès). Be to, visi palaidotieji - 20-30 m. vyrai, o nužudyti sukilimo vadai buvo vyresni.

1996 m. pritaikant Senojo arsenalo kieme esantị XX a. pradžioje statytą ūkinị dviaukštị pastatą Lietuvos nacionalinio muziejaus bibliotekai, kasinètas $35 \mathrm{~m}^{2}$ plotas (tyrimų vadovas - Andrius Vaicekauskas). Aptikti du dvigubi kapai ${ }^{13}$. Abiejuose kapuose, apie $1 \mathrm{~m}$ pločio duobèse, palaidoti 25-40 metų vyrai. Traumų pèdsakų palaikuose nepastebèta. Be to,

9 Senojo arsenalo kiemas, Vrublevskio g. 3. Preliminari skeletų lyties, amžiaus, etc. diagnostika. Idètiniai lapai ataskaitoje: Raškauskas V., $1988 \mathrm{~m}$. archeologinių tyrinëjimų Vilniuje, Vrublevskio g. 3, ataskaita. I dalis. LIIR, f. 1, b. 1610, p. 38-42.

${ }^{10}$ Raškauskas V., 1988 m. archeologinių tyrinèjimų Vilniuje, Vrublevskio g. 3, ataskaita. I dalis. Vilnius, 1989 m. LIIR, f. 1, b. 1610, p. 37.

${ }^{11}$ K. Katalynas dalyvavo tai konstatavusios komisijos darbe.

${ }^{12}$ Jogèla V., Meilus E., Pugačiauskas V. Lukiškès: nuo priemiesčio iki centro (XVXX a.). Vilnius, 2008, p. 232-234.

${ }^{13}$ Vaicekauskas A. 1996 m. Vilniuje, Arsenalo g. 3, vykdytų archeologinių tyrimų ataskaita. Vilnius, 1997 m. LIIR, f. 1, b. 2653, p. 22. 
tyrimų vietoje buvo rasta ir daugiau mirusiųjų kaulų, kurie priskirtini tam pačiam laikotarpiui kaip ir keturi dvigubi kapai, suardyti vèlesniais laikais atliekant žemès judinimo darbus ${ }^{14}$. Mirusieji buvo palaidoti karstuose, galvomis ị pietvakarius. İkapių neaptikta. A. Vaicekauskas, remdamasis 1988 m. tyrimų vadovo V. Raškausko nuomone (žr. aukščiau) ir faktu, kad greta kapų buvo XIX a. II puse datuoto medinio pastato liekanų, kapus taip pat datavo XIX a. ${ }^{15}$

Nepakankamai pagrịsta prielaida, kad šioje Žemutinès pilies dalyje palaidoti mirties bausme nubausti 1863-1864 m. sukilimo dalyviai, kai kurių visuomenès atstovų buvo priimta kaip istorinè tiesa. $2012 \mathrm{~m}$. liepos $18 \mathrm{~d}$. tuometis užsienio reikalų ministras Audronius Ažubalis ir kardinolas Audrys Juozas Bačkis atidengė atminimo lentą (autorius - architektas Rimas Grigas) ant Senojo arsenalo pastato (Arsenalo g. 3A) sienos. Atidengti atminimo lentą paskatino ne tiek konkretūs archeologiniai radiniai, kiek netiesioginès prielaidos. Esą XIX a. antroje pusèje Senajame arsenale, dabartiniame Taikomosios dailès muziejuje, buvo ịrengtos sukilimą malšinusių carinès Rusijos kazokų kareivinès. Remiantis atsiminimais, šių kareivinių kiemelyje, tikètina, buvo žiauriai nukankinti sukilimo dalyviai. Nors faktą patvirtinančių archeologinių duomenų trūksta, vis dèlto šis kiemelis galètų tapti viena iš sukilimą simboliškai ịprasminančių vietų. A. Ažubalis vylèsi, kad istorikų ir archeologų pastangomis bus galutinai nustatytos konkrečių sukilèlių, kurie, manoma, buvo palaidoti Žemutinès pilies teritorijoje, pavardès ${ }^{16}$. Memorialinès lentos atidengimas, neturint pakankamai tikslios mokslinès informacijos ir aiškių ịrodymų, kad čia palaidoti nužudyti sukilimo dalyviai, o ne, tarkime, XVII a. viduryje Vilnių okupavę maskvėnai, netrukus sulaukè vieno iš šio straipsnio bendraautorių K. Katalyno kritikos ${ }^{17}$.

14 Barakauskas S. 1996 m. archeologinių tyrinejjimų Vilniuje, Arsenalo g. 3, antropologinio tyrimo ataskaita. Idetiniai lapai ataskaitoje: Vaicekauskas A. 1996 m. Vilniuje, Arsenalo g. 3, vykdytų archeologinių tyrimų ataskaita. Vilnius, 1997 m. LIIR, f. 1, b. 2653, p. 24-26.

15 Vaicekauskas A. 1996 m. Vilniuje, Arsenalo g. 3, vykdytų archeologinių tyrimų ataskaita. Vilnius, 1997 m. LIIR, f. 1, b. 2653, p. 6-8, 22, nuotr. Nr. 2, brěž. Nr. 2.

16 Vilniuje atidengta atminimo lenta 1863-1864 metų sukilimo dalyviams. Interneto prieiga: http://www.delfi.lt/news/daily/lithuania/vilniuje-atidengta-atminimo-lenta18631864-metu-sukilimo-dalyviams.d?id=59138997 [tikrinta 2012-11-15]

17 K. Katalynas žiniasklaidoje pareiškė nuomonę, kad reikètų nuimti memorialinę lentą ir galvoti apie sukilèlių atminimo pagerbimą Lukiškių aikštėje - jų mirties bausmès Łvykdymo vietoje. Savo ruožtu archeologas Gintautas Striška žiniasklaidai teigè, kad ,is- 
1655-1661 m. Rusijos kariuomenès karių kapavietė. 2003 m. Senojo arsenalo kiemo pietvakariniame kampe, Pilies kalno šiaurinèje papèdejje, tirtas $140 \mathrm{~m}^{2}$ plotas (vadovas - G. Striška). Perkasos rytinèje dalyje, kalno šlaito apatineje dalyje, aptikti devyni kapai. Mirusieji palaidoti karstuose, galvomis i pietvakarius (azimutas $\sim 240^{\circ}$ ), aukštielninki, rankos sudètos ant krūtinès arba dubens. Manoma, kad kai kurie (Nr. 1, Nr. 2, Nr. 7 ir Nr. 3, Nr. 4, Nr. 8) galèjo būti palaidoti vienoje (bendroje) duobejje. Visuose kapuose rasta karsto vinių. Dalis jų, didelėmis galvutėmis, skirtos durims ar vartams apkalti. Kapuose Nr. 5 ir Nr. 6 aptikta geležies juostelių, kurios veikiausiai buvo skirtos karstams sutvirtinti. Kape Nr. 8 aptikta bronzinè saga. Kape Nr. 6, šalia palaikų dešiniojo kelio, rasta Zigmanto III Vazos 1611-1613 m. emisijos rusiška biloninẻ kapeika (tokios monetos buvo apyvartoje iki XVII a. vidurio imtinai). Autorius padarè išvadą, kad rasti Žemutinèje pilyje apsuptos Rusijos kariuomenès igulos karių, mirusių nuo epidemijų, palaikai ${ }^{18}$. Vilnius iš rusų okupacijos galutinai buvo išvaduotas $1661 \mathrm{~m}$. gruodžio $3 \mathrm{~d} .{ }^{19}$

Tokios išvados visiškai dera su palaikų antropologinès analizės duomenimis. Paaiškejjo, kad aštuoneri yra vyrų, o vieni (kape Nr. 6) - apie $12 \mathrm{~m}$. vaiko palaikai. Suaugusiųjų amžius (septyni atvejai) svyravo nuo $20 \mathrm{iki}$ 40 m., vienas mirusysis (palaidotas kape Nr. 9) buvo vyresnis (50-55 m.). Be to, aptikta pavienių žmonių kaulų iš suardytų kapų: vienas $20-30 \mathrm{~m}$.

torinių duomenų, kad čia [Žemutinès pilies teritorijoje] palaidoti sukilimo dalyviai, nèra, bet kas gali paneigti, kad jie ten galètų būti“, o istorikas Vytautas Jogèla neatmetè nei XIX a. sukilèlių, nei XVII a. maskvėnų palaidojimo kapavietėse Senojo arsenalo kieme galimybès. Be to, V. Jogèla teigè radęs užuominų lenkų spaudoje, kad sukilimo dalyviai, ịvykdžius mirties bausmę, galbūt galèjo būti palaidoti Šv. Mykolo bažnyčioje arba Gedimino kalne. Tačiau tai, V. Jogèlos manymu, veikiau spejjimai. Galiausiai Užsienio reikalu ministerijos Visuomenès informavimo skyriaus vadovas Mindaugas Lašas patikslino, kad i̇amžinti žuvusių sukilèlių atminimą prie Senojo arsenalo pasiūlè Tūkstantmečio direkcija dar 2005 m. Tiksli palaikų palaidojimo vieta nėra žinoma, todèl Senasis arsenalas pasirinktas kaip vienas seniausių istorinių Vilniaus pastatų. Žr.: Gudavičiūtė D. Tautos didvyrius įamžino ant skerdikų kapų? Interneto prieiga: http://bendraukime.lrytas.lt/aktualijos/tautos-didvyrius-iamzino-ant-skerdiku-kapu.htm [tikrinta 2012-11-15]

18 Striška G. Vilniaus pilies teritorija. Keleivinio keltuvo aikštelių Arsenalo kieme ir Pilies kalne $2003 \mathrm{~m}$. archeologinių tyrimų ataskaita. T. 1. Vilnius, $2007 \mathrm{~m}$. Lietuvos nacionalinio muziejaus Viduramžių ir naujųjų laikų archeologijos skyriaus archyvas, b. 554, p. 25-30, 80 .

19 XVII a. vidurio Maskvos okupacijos Lietuvoje šaltiniai. T. 1. 1657-1662 m. Vilniaus miesto Tarybos knyga (sudarė Elmantas Meilus). Vilnius, 2011, p. 12. 
vyro kaukoles skliautas, vyro žastikaulis, trys vyrų blauzdikauliai, penki padikauliai. Kai kuriuose palaikuose pastebèta traumų pėdsakų. Kape Nr. 3 palaidoto $25-30 \mathrm{~m}$. vyro kairysis žastikaulis buvo lūžęs ir prieš mirtị nesugijęs. Kape Nr. 5 palaidotas 35-40 m. vyras buvo patyręs kairiojo delnikaulio ir vieno dešiniojo šonkaulio lūžius, kurie prieš mirtị jau buvo sugiję. Kape Nr. 9 palaidotas 50-55 m. mirusysis buvo patyręs nosies ir kelių kairès pusès šonkaulių lūžius, kurie sugijo iki mirties, ir sirgo galimai dèl traumos atsiradusiu kairès kojos nykščio sąnarių osteoartritu ${ }^{20}$.

Tikètina, kad su 1655-1661 m. maskvènų okupacijos periodu gali būti susiję ir 1955 m. Pilies kalno pietvakarinèje papèdèje vykusių archeologinių tyrimų metu rasti du kapai. Kape Nr. 1, kuris aptiktas $40 \mathrm{~cm}$ gylyje, palaidotas mirusysis buvo paguldytas ant nugaros (azimutas $\sim 230^{\circ}$ ), rankos sulenktos, plaštakos sudètos pilvo srityje. Rastos kelios vinys (greičiausiai karsto), įkapių neaptikta. Konstatuota, kad šalia galèjo būti kitų kapų, kurie suardyti ịvairių perkasimų metu (šalia permaišytame sluoksnyje rasta žmonių kaulų). Iš gerai išlikusių, sveikų mirusiojo dantų tyrèjai padarè išvadą, kad kape palaidotas jaunas žmogus. Kape Nr. 2, kuris buvo tokiame pat gylyje kaip ir kapas Nr. 1, palaidotas mirusysis buvo paguldytas ant nugaros, rankos sukryžiuotos pilvo srityje. Mirusysis orientuotas galva i šiaurès vakarus $230^{\circ}$ azimutu, palaidotas mediniame karste iš pušinių (?) $2-3 \mathrm{~cm}$ storio lentų. Karste šalia mirusiojo galvos buvo rastas „pusiau perlaužtas medinis kotas ir smailejjančia viršūne peilis" ${ }^{{ }_{21}}$.

Su 1655-1661 m. ịvykiais sietini kapai buv. Šv. Onos ir Barboros bažnyčios teritorijoje. 1955-1959 m. vyko A. Tautavičiaus vadovaujami didelès apimties archeologiniai tyrimai šiaurineje Pilies kalno papèdeje. Jų metu buvo rasta Šv. Onos - Šv. Barboros bažnyčios, stovejusios čia 1551-1666 m., o jos viduje - mažos Šv. Onos bažnytèlès, stovèjusios XIV a. pab.-1551 m., liekanų. Bažnyčios viduje ir aplink ją rasta 70 kapų. Tyrejjui krito ị akis, kad dalis kapų netvarkingi, mirusieji palaidoti

20 Jankauskas R. Žmonių palaikų iš keltuvo ị Pilies kalną Vilniuje apatinès aikštelès (Arsenalo g. 3) antropologinès analizès rezultatai. Idetinis nenumeruotas lapas ataskaitoje: Striška G., Vilniaus pilies teritorija. Keleivinio keltuvo aikštelių Arsenalo kieme ir Pilies kalne 2003 m. archeologinių tyrimų ataskaita. T. 1. Lietuvos nacionalinio muziejaus Viduramžių ir naujųjų laikų archeologijos skyriaus archyvas (toliau - ARMA), b. 554.

21 Daugudis V., Kulikauskas P., Tautavičienė B., Tautavičius A. Žvalgomųjų archeologinių tyrinejjimų Gedimino kalno pietvakarinejje pašlaitèje dienoraštis (1955.V.24-VII.4). LII R, f. 1, b. 36, p. 11-13. 
netipiškomis pozomis. Buvo rasta ir grupinių kapų, kuriuose palaidota po du mirusiuosius. A. Tautavičius padare išvadą, kad kapinèse laidota maždaug nuo 1390 m., kai čia pastatyta pirmoji Šv. Onos bažnyčia, iki 1551 m., kai pradèti naujos bažnyčios statybos darbai. Visgi dalis kapų, ypač teritorijoje greta bažnyčios, yra vèlesni ir A. Tautavičiaus siejami su 1655-1661 m. ìvykiais ${ }^{22}$. Galbūt dalis šių, anot A. Tautavičiaus, „netvarkingų kapų“ yra Vilniaus pilių komplekse apsuptos maskvenų igulos narių palaikai, juolab kad visiškai netoli šios vietos, dabartinio funikulieriaus žemutinès aikštelès vietoje, vykdytų tyrimų metu rasti mirusiųjų palaikai būtent taip interpretuojami.

Be to, Šv. Onos - Šv. Barboros bažnyčios vietoje rasti keli kapai, ịrengti jau po to, kai ši bažnyčia buvo apleista ir sugriauta XVII a. viduryje karų metu (griuvėsiai galutinai sulyginti 1666 m.). 1957 m. vykdytų tyrimų metu rasti kapai Nr. 1-3. Jie buvo vos 35-60 cm giliau negu XVIII a. ịrengtas akmenų grindinys. ̨̦kapių nerasta. Tąsyk A. Tautavičius padare išvadą, kad mirusieji šioje vietoje palaidoti XVII a. pabaigoje arba XVIII a., kai bažnyčia jau buvo nugriauta ${ }^{23} .1960$ m. tęsiant Šv. Onos - Šv. Barboros bažnyčios ir jos aplinkos tyrimus, rastas dar vienas kapas - Nr. 1 (65), duobè kuriam, kaip ir minètiems trims 1957 m. rastiems kapams, buvo i̇rengta tarp statybinių griuvenų, apgriovus arba galutinai nugriovus bažnyčią. Mirusiojo krūtinès srityje rastos kelios smulkios XVII a. monetos ${ }^{24}$. Gali būti, kad šie kapai datuotini ne XVII a. pab.-XVIII a., kaip mané A. Tautavičius, bet XVII a. viduriu, kaip ir daug kitų Žemutinès pilies dalyje rastų kapų. Sunkiomis sąlygomis, karinès apgulos ar epidemijos metu palaidoti mirusiuosius tarp bažnyčios griuvenų buvo gana nesudètinga.

Antrojo pasaulinio karo SSRS ir Vokietijos karių kapavietès. Žemutinès pilies teritorijoje $1944 \mathrm{~m}$. vyko intensyvūs karo veiksmai. Tai liudija įvairiais metais vykusių archeologinių tyrimų metu rasti artefaktai.

22 Tautavičius A. Vilniaus pilies teritorijos archeologiniai kasinèjimai // Valstybinès LTSR architektūros paminklų apsaugos inspekcijos metraštis. T. II. Vilnius, 1960, p. 17-18.

23 Tautavičius A. Archeologinių tyrinèjimų Vilniuje, Gedimino kalno šiaurinëje papèdèje, buvusios Žemutinès pilies teritorijoje, dienoraštis (1957.IV.24-1957.XI.2). LIIR f. 1, b. 65 , p. $19-22$.

${ }^{24}$ Tautavičius A., Navickas K., Sadauskaitè-Mulevičienè I. Ataskaita už archeologinius kasinèjimus Vilniuje, Gedimino kalno šiaurinèje papèdèje, buvusios Vilniaus Žemutinès pilies teritorijoje, nuo 1960 m. gegužès 12 d. iki spalio 30 d. LII R, f. 1, b. 92, p. 3-4. 
1955 m. atliekant archeologinius kasinèjimus (vadovas - Adolfas Tautavičius) šiaurinèje Pilies kalno papėdeje, tyrimų plote Nr. 1 aptikta daug tai liudijančių radinių: daugybẻ šovinių tūtelių, dujokaukių dalių, spygliuotos vielos fragmentų, vokiškas šalmas ir kitų kariškų atributų ${ }^{25}$. Panašių radinių (šovinių, „faustpatronų“, minų, butelių su degiuoju skysčiu, šalmų) rasta ir 1957 m. šioje teritorijoje (buv. Šv. Onos ir Šv. Barboros bažnyčios aplinkoje) atliekant archeologinius tyrimus ${ }^{26}$.

$1994 \mathrm{~m}$. birželio ménesį vykdant archeologinius žvalgymus (vadovas - Saulius Sarcevičius) inžinerinių komunikacijų tiesimo metu neužstatytame plote tarp pastato Arsenalo g. 3 ir Arsenalo gatvès, dviejose vietose buvo rasta karių kapų. Vienu atveju aptikti trijų asmenų palaikai, suguldyti vienas ant kito. Dveji griaučiai buvo galvomis orientuoti i pietvakarius, vieni - $\mathfrak{i}$ šiaurès rytus. Archeologinių žvalgymų ataskaitoje jie ivvardyti kaip kapai Nr. 1, Nr. 2 ir Nr. 3. Kape Nr. 1 aptikta šovininė su 5 šoviniais (taip parašyta ataskaitoje; veikiausiai turèta galvoje šautuvo šovinių apkaba), diržo sagtelè su $3 \mathrm{~cm}$ pločio odinio diržo fragmentu ir dveji odiniai batai. Kape Nr. 2 rastas kario individualiojo paketo fragmentas, skutimosi peiliukas ir šovininè su trimis šoviniais, kape Nr. 3 - trys geležinès sagtelès, žalvarinis žiedas ir dvi metalinès sagos su žvaigždėmis. Archeologinių žvalgymų autoriaus S. Sarcevičiaus nuomone, kapavietẻje aptikti Raudonosios armijos karių palaikai; žūties laiko ir aplinkybių jis ataskaitoje netikslino ${ }^{27}$. Antropologinių tyrimų metu konstatuota, kad visi trys palaidoti asmenys buvo vyrai, jų amžius - 20-25, 30-40 ir 40-50 m. Palaikuose fiksuoti kai kurių šonkaulių, vieno delnikaulio, vieno stipinkaulio, vieno žandikaulio perimortaliniai (patirti mirties ar laidojimo metu) lūžiai ${ }^{28}$.

Tautavičius A. Vilniaus Pilies kalno šiaurinèje papėdèje vykdytų $1955 \mathrm{~m}$. nuo rugsèjo 14 d. iki lapkričio 25 d. kasinejjimų dienoraštis. Isegta byloje: Archeologiniai tyrinejjimai Gedimino kalno aplinkoje, 1955 m./ LII R, f. 1, b. 36, p. 9-12 (pagal tęstinę visos bylos numeracija - p. 55-58).

26 Tautavičius A. Archeologinių kasinėjimų Vilniuje, Gedimino kalno šiaurinèje papèdejje, buvusios Žemutinès pilies teritorijoje, dienoraštis (1957.IV.24-1957.XI.2). LII R, f. 1 , b. 65 , p. 35 .

27 Sarcevičius S. Vilnius 94, Arsenalo 3. Lietaus kanalizacijos archeologinès priežiūros ataskaita. LIIR f. 1, b. 2356, p. 21, 26.

28 Jankauskas R. Vilniuje, Arsenalo g. 3, rastų palaikų apžiūros aktas. Idetiniai lapai ataskaitoje: Sarcevičius S. Vilnius 94, Arsenalo 3. Lietaus kanalizacijos archeologinès priežiūros ataskaita. LIIR f. 1, b. 2356, p. 21, p. 28-29. 
Netoli Raudonosios armijos karių palaikų radimo vietos buvo aptikti dar aštuonių asmenų palaikai, netvarkingai suguldyti vienas ant kito trimis eilemis. Kapavietė apardyta. Aptikti penki aliumininiai kario identifikavimo žetonai, aliumininė gertuvè, sagčių, metalinių ir plastmasinių sagų, rūbų užsegimo kilpelių, geležinių grandelių, šovinys. Sprendžiant iš radinių, šie asmenys buvo Vokietijos ginkluotụjų pajègų kariai. Autoriaus nuomone, jų grupinis kapas atidengtas tik iš dalies ${ }^{29}$. Antropologinių tyrimų metu konstatuota, kad visi palaidoti asmenys buvo vyrai, jų amžius svyravo nuo 20 iki 50 metų. Palaikuose fiksuoti perimortaliniai alkūnkaulių (du atvejai), šlaunikaulio (vienas atvejis) ir blauzdikaulio (vienas atvejis) lūžiai. Kaukolè Nr. 5, anot R. Jankausko, suskilusi laidojimo metu, o šlaunikaulyje rasta šautinè žaizda - kulkos iejimo vieta iš šono ${ }^{30}$.

Abiejų kovojusių pusių kariai yra žuvę SSRS kariuomenei puolant, o Vokietijos kariuomenei ginant Vilnių 1944 m. liepos mènesį. Per vasaros karščius žuvusiųjų palaikai buvo paskubomis užkasti.

Baigus tyrimus, apie radinius buvo informuotos paveldosaugos institucijos ir Vilniaus miesto komisija dèl rezistentų ir kitų asmenų, nužudytų okupacinių režimų metu, palaikų perkèlimo ir palaidojimo vietų jamžinimo. Ir sovietinių, ir vokiečių karių palaikai buvo perlaidoti Antakalnio kapinèse ${ }^{31}$.

Antrojo pasaulinio karo Vokietijos karių palaikai. Antrojo pasaulinio karo Vokietijos kariuomenès karių palaikų Žemutinès pilies teritorijoje rasta net keliose vietose. $1956 \mathrm{~m}$. vasarą atliekant archeologinius tyrimus Pilies kalno šiaurineje papėdeje, aptikti vieno ar net kelių vokiečių karių palaikai. „Nuimant viršutinị sluoksnị tuoj po smèliu, pačiame šiauriniame pakraštyje, rastas kapas - palaidotas vokiečių karys ir liekanos karo metu įrengto blindažo. 1956.VIII.6 iš blindažo liekanų šiaurineje perkaso sienoje matyti, kad <...> blindažo gylis $2 \mathrm{~m}$, plotis $-2,7 \mathrm{~m}$, sienos išgrịstos lentomis. Lubas palaikè stulpai kampuose. $<\ldots>$ Vokiečiai

${ }^{29}$ Sarcevičius S. Vilnius 94, Arsenalo 3. Lietaus kanalizacijos archeologinès priežiūros ataskaita. LIIR f. 1, b. 2356, p. 21, p. 21, 25-30.

${ }_{30}$ Jankauskas R. Vilniuje, Arsenalo g. 3, rastų palaikų apžiūros aktas. Idètiniai lapai ataskaitoje: Sarcevičius S. Vilnius 94, Arsenalo 3. Lietaus kanalizacijos archeologinės priežiūros ataskaita. LIIR f. 1, b. 2356, p. 21, p. 29-30.

${ }^{31}$ Sarcevičius S. Vilnius 94, Arsenalo 3. Lietaus kanalizacijos archeologinės priežiūros ataskaita. LIIR f. 1, b. 2356, p. 21, 31-36. 
buvę palaidoti labai negiliai apie 3,3 m nuo blindažo i̇ vakarus.“"32 Taigi, iš ataskaitos teksto neaišku, ar rastas vienas, ar keli vokiečiu karių kapai. Kas buvo daroma su rastais palaikais, ataskaitoje nenurodoma.

$2004 \mathrm{~m}$. vykdant archeologinius tyrimus (vadovai - D. Steponavičienè ir P. Blaževičius) Valdovų rūmų šiaurinèje pusèje, antrosios oficinos vietoje, buvo rasti treji žmonių palaikai. Jie buvo kniūbsti suguldyti viename kape. Griaučius peraugo medžių šaknys. Greta rasti karių žetonai, sagos, antpečių liekanos liudijo, kad čia palaidoti Antrojo pasaulinio karo metais žuvę vokiečių kariai. Šio kapo aplinkoje taip pat rastas vokiškas šalmas, batų pasagèlès, durklo makštys, daugybè šovinių tūtelių, minosvaidžio sviedinio dalis ir kitų karo laikų artefaktų ${ }^{33}$. Antropologinių tyrimų metu konstatuota, kad kape palaidoti du 35-45 m. (kapai Nr. 1 ir Nr. 3) ir vienas 30-40 m. (kapas Nr. 2) vyrai ${ }^{34}$.

Taip pat 2004 m. archeologai Vytautas Urbanavičius ir Daiva Steponavičienė perdavė Vokiečių karių kapų globos tautinès sạjungos ekshumuotųjų grupés Lietuvoje vadovui Manfredui Drobei (Manfred Drobe) septyniu kariu palaikus, aptiktus tyrimų Žemutinès pilies teritorijoje metu. Dalis šiu palaikų (keturių asmenų kaulai) buvo rasti dar $1964 \mathrm{~m} .{ }^{35}$ Tuomet Žemutinès pilies teritorijoje dirbusi archeologinè ekspedicija, vadovaujama Adolfo Tautavičiaus, atliko tyrimus būsimos šiluminès trasos tiesimo vietoje. Tyrimų metu buvo aptikti kelių vokiečiu karių palaikai. Tiesa, ataskaitoje rašoma, kad rasti trijų vokiečių karių palaikai (nors $2004 \mathrm{~m}$. atkastoje dèžèje buvo keturių žmonių kaulai). Archeologinių tyrimų ataskaitoje yra A. Tautavičius $1964 \mathrm{~m}$. rugpjūčio $31 \mathrm{~d}$.

2 Tautavičius A. LTSR MA Istorijos instituto vykdytų archeologinių kasinëjimų Vilniuje Gedimino kalno šiaurinèje papèdèje 1956.V.14-X.3 dienoraštis. LII R, f. 1, b. 36, p. 20.

${ }^{33}$ Steponavičienė D., Blaževičius P. II oficinos Vilniaus Žemutinès pilies teritorijoje tyrimai 2004-2005 m. // Archeologiniai tyrinèjimai Lietuvoje 2005 metais. Vilnius, 2006, p. 151-152; Volksbund Deutsche Kriegsgräberfürsorge e. V. Umbettungsbericht. Vilnius Kathedralplatz „Untere Burg“', 06.09.-07.09. 2004. Vergebene U-Nr.: 017-019 (V̌̌t Kultūros vertybiu globos tarnybos archyvas).

${ }^{34}$ Jankauskas R., Barkus A., Urbanavičius A. II oficinos Vilniaus Žemutinès pilies teritorijoje tyrimai 2004-2005 m. // Archeologiniai tyrinèjimai Lietuvoje 2004 metais. Vilnius, 2006, p. 357-358.

35 Volksbund Deutsche Kriegsgräberfürsorge e. V. Umbettungsbericht. Vilnius Kathedralplatz, Krs. Vilnius, Bez. Vilnius. 04.08.1964 - 06.09.-07.09. 2004. Vergebene U-Nr.: 020-023 (Všt Kultūros vertybiu globos tarnybos archyvas). 
parengtas aktas, kuriame rašoma: „Kasant trasą, $1964 \mathrm{~m}$. rugpjūčio $4 \mathrm{~d}$., $6 \mathrm{~m}$ ị šiaurę nuo Pionierių rūmų [vad. Šliosbergo namo, XIX a. pr. pastatyto panaudojant Valdovų rūmų rytinio korpuso griuvésius - aut. past.] garažo galo buvo aptikti treji žmonių griaučiai vos $20-40 \mathrm{~cm}$ gylyje. Tarp jų rasta pusapvalè nulaužtu kraštu skardelè [kario identifikavimo žetonas - aut. past.] su dviem apskritomis skylutemis ir įmuštu įrašu „3605 BL. AB Stamm Komp. Kf. Ers. Abt. 8“, kita tokia pat visai sunykusi skardelè su neišskaitomu įrašu ir trečia keturkampe aliumininè skardele su skaitline „10.43“. Be to, buvo likusios žymès kelių vokiško munduro sagų. Matyt, čia yra $1944 \mathrm{~m}$. vasarą užkasti hitlerinės armijos kareiviai. Tarp kaulų surastas auksinis (?) vestuvinis žiedas, kurio vidinėje pusèje yra inicialai „E.TH“ ir data „19 16/8 32“. Griaučiai sudetti ị medinę dèžę ir užkasti ten pat trasos dugne. Žiedas kartu su vienu egzemplioriumi šio akto perduodamas Vilniaus miesto Lenino rajono milicijos skyriaus radinių stalui “' ${ }^{36} .1964 \mathrm{~m}$. děžeje užkasti vokiečių karių palaikai dar kartą atrasti $2004 \mathrm{~m}$. Aptikti palaikai iš pirminès trijų asmenų ir antrinès keturių asmenų kapaviečiu buvo perduoti Vokiečių kariụ kapų globos tautinès sajungos (Vokietija) atstovams ir perlaidoti vokiečių karių kapinèse Vingio parke ${ }^{37}$.

Kiti spèjami karių kapai. Vilniaus Žemutinès pilies teritorijoje galëjo būti rasta ir daugiau karių kapų. A. Tautavičius 1955 m. archeologinių tyrimų ataskaitoje užsimena, kad šioje Vilniaus dalyje „XX a. pradžioje, vykdant statybos darbus, buvo aptiktas ištisas kapinynas, kuris palaikytas $1812 \mathrm{~m}$. prancūzų kapais" ${ }^{{ }_{38}}$. Tačiau lieka neaišku, kokiais šaltiniais remiamasi pateikiant šią informaciją.

$1955 \mathrm{~m}$. vykdant archeologinius tyrimus (vadovas - A. Tautavičius) šiaurinèje Pilies kalno papèdèje, tyrimų plote Nr. 1 rasti du suardyti kapai

36 Tautavičius A. Per Vilniaus Žemutinès pilies teritoriją $1964 \mathrm{~m}$. birželio 22-rugsèjo 9 d. kastos šiluminès trasos archeologinių stebejjimų duomenys. Vilnius, 1965. LIIR f. 1, b. 227 , p. 21 , p. 53 .

37 S. Natkevičiaus žodinè informacija (2012 m. lapkričio 22 d.).

38 Tautavičius A. Vilniaus Pilies kalno šiaurinejje papėdejje vykdytų $1955 \mathrm{~m}$. nuo rugsèjo $14 \mathrm{~d}$. iki lapkričio $25 \mathrm{~d}$. kasinejjimų dienoraštis. Isegta byloje: Archeologiniai tyrinejjimai Gedimino kalno aplinkoje, 1955 m./ LII R, f. 1, b. 36, p. 2 (pagal tęstinę visos bylos numeracija-p. 48). 
be ikkapių. Atstumas tarp kapų - 4,4 m². Tikètina, kad šie pavieniai kapai taip pat sietini su šioje vietoje vykusiais karo veiksmais, tačiau tikslesnei interpretacijai stinga duomenų.

\subsection{Kalnų parko teritorija}

1655-1661 m. LDK karo su Rusija aukų kapai. 1989 m. vyko archeologiniai tyrimai dabartinio Kalnų parko teritorijoje. Tyrimams vadovavo archeologè Daiva Misiukaitè (Luchtanienè). Dviejose vietose buvo rasta žmonių kapų. Bekešo kalno (didžioji dalis jo nuplauta Vilnelès) likučių pietinëje dalyje, tiriant šurfą Nr. 7, rasta žmonių palaikų. Išplètus tyrimų plotą, iš viso aptikta dešimt kapų, kuriuose buvo palaidota 30 žmonių. Dalis kapų buvo grupiniai (vienoje kapo duobeje palaidota po du, keturis, septynis mirusiuosius). Mirusieji (vyrai, moterys, paaugliai ir vaikai) laidoti gana chaotiškai: vieni atloštomis galvomis, kiti ant šono arba virš galvos sudètomis rankomis. Kai kurių mirusiųjų rastos tik griaučių dalys. Mirusieji laidoti galva ị šiaurę ir šiaurès vakarus. Karstų likučių nepastebèta, nors rasta kaltinių vinių. Mirusieji laidoti be ¡kapių. Tik kape Nr. 2 rasta $\mathrm{Zi}$ gmanto III Vazos moneta - dvidenaris, nukaldintas 1620 metais, o grupiniame kape Nr. 6 - metaliniu sagur, sagtis, bato pasagèlè, stiklo karoliuku. Tyrèja, remdamasi rasta mo-

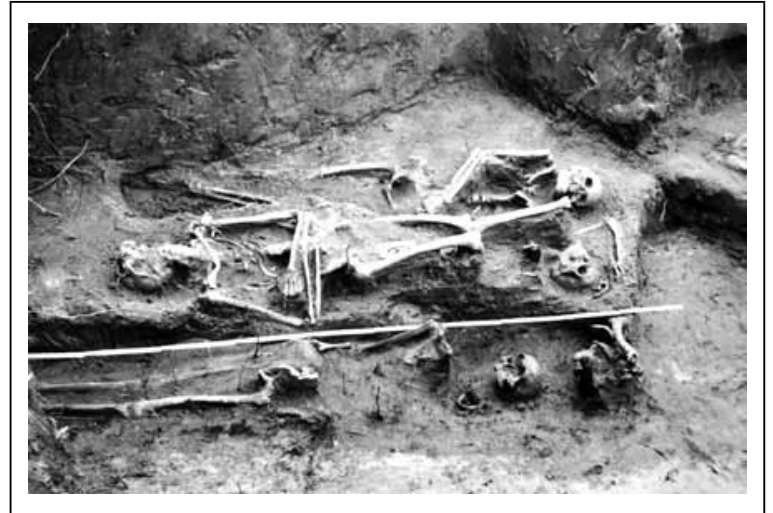

3 pav. Archeologiniai tyrimai Kalnų parko teritorijoje 1989 m. Grupinis kapas Nr. 6. Misiukaite D. Vilniaus piliu muziejaus-draustinio teritorijos ribu nustatymas. Žvalgomieji archeologiniai tyrimai. Ataskaita. LII R, b. 1668

39 Tautavičius A. Vilniaus Pilies kalno šiaurineje papèdejje vykdytų $1955 \mathrm{~m}$. nuo rugsèjo $14 \mathrm{~d}$. iki lapkričio $25 \mathrm{~d}$. kasinèjimų dienoraštis. Isegta byloje: Archeologiniai tyrinèjimai Gedimino kalno aplinkoje, 1955 m./ LII R, f. 1, b. 36, p. 9, 11 (pagal tęstinę visos bylos numeracija - p. 55, 57). 
neta ir laidojimo pobūdžiu (grupiniai kapai), padarẻ logišką išvadą, kad Kalnų parko teritorijoje rasti kapai veikiausiai sietini su 1655-1661 m. rusų vykdyta Vilniaus okupacija. Kitoje Kalnų parko teritorijos vietoje, Gedimino kapo kalno aikštelès pietinèje dalyje, buvo aptiktas kapas, kuriame vienoje duobeje, lentiniuose, geležinèmis vinimis sutvirtintuose karstuose, buvo palaidoti keturi asmenys ${ }^{40}$. Abiejose kapavietèse rasti grupiniai kapai veikiausiai yra vieno laikotarpio ir sietini su tragiškais XVII a. ịvykiais Vilniuje. Sunkiau pasakyti, ar šie kapai yra karių.

Neaiški kapavietė. Kreivojo, kitaip - Trijų Kryžių, kalno šiaurinėje papèdejje, ties ịvažiavimu iš Kosciuškos gatvès ị Kalnų parko teritoriją, SSRS kariuomenès kariai, lygindami šlaitą, 1955 m. atkasè apie dešimt griautinių kapų. Darbų vietoje apsilankęs archeologas Pranas Kulikauskas užfiksavo, kad mirusieji orientuoti galvomis ị rytus, kapai - be įkapių. Konstatuota, kad tai veikiausiai vèlyvi kapai ${ }^{41}$. Ar jie ir 1989 m. tirti kapai Kalnų parko teritorijoje gali būti vienalaikiai, sunku pasakyti, nes išsamesnè 1955 m. atkastų kapų fiksacija nebuvo atliekama.

\subsection{Karaliaus Mindaugo tilto prieigos (Žygimantų, T. Vrublevskio, Arsenalo gatvių sankirta)}

Antrojo pasaulinio karo SSRS karių kapavietė. 2002 m. kovo mènesị buvo pradèti Karaliaus Mindaugo tilto per Nerị statybos darbai. Jų metu statybininkai aptiko žmonių kaulų. Pradejus archeologinius tyrimus (vadovai - Gediminas Gendrènas ir Egidijus Ožalas), ištirtas maždaug 5x5 m dydžio plotas. Jame rasti penkių Raudonosios armijos karių palaikai. Mirusieji buvo paguldyti ant nugaros, ištiestomis rankomis, galvomis ị šiaurę - šiaurès rytus (link Neries upès). Palaikų antropologinę analizę atliko Arūnas Barkus. Palaidotųjų amžius - maždaug nuo 20 iki 35-45 metų. Sprendžiant iš kai kurių ịkapių (dviejų gvardijos ženkliukų

40 Misiukaitė D. Vilniaus pilių muziejaus-draustinio teritorijos ribų nustatymas. Žvalgomieji archeologiniai tyrimai. Ataskaita. LII R b. 1668, p. 8-12, 15, 17-20; Misiukaitė D. Vilniaus kalnų parko teritorijos žvalgomieji tyrimai // Archeologiniai tyrinèjimai Lietuvoje 1988 ir 1989 metais. Vilnius, 1990, p. 153-154.

41 Kulikauskas P. 1955 m. archeologiniai žvalgymai Vilniaus Kreivosios pilies, arba Trijų Kryžių kalno, rajone. Isegta byloje: Archeologiniai tyrinejjimai Gedimino kalno aplinkoje, 1955 m./ LII R, f. 1, b. 36, p. 1-3 (pagal tęstinę visos bylos numeracija - p. 130-132). 
ir vieno ženklo „Pasižymėjęs tankistas“ bei antsiuvo su tanko atvaizdu), bent trys iš palaidotųjų buvo tankistai. Be asmeninių daiktų (šukų, veidrodèlio, cheminio pieštuko fragmentu, buteliuko) ir aprangos detaliu (batų, antsiuvo su tanko atvaizdu, sagčių, diržų skirstiklių, sagų), aptiktas kastuvèlis, 100 pistoleto TT šovinių ir dvi prieštankinès granatos. Palaikai buvo preparuojami dalyvaujant išminuotojams, jie išsivežè rastas granatas ir šovinius. Žuvę asmenys neidentifikuoti. Palaikai, dalyvaujant Rusijos, Ukrainos ir Baltarusijos diplomatinių atstovybių atstovams, perlaidoti Antakalnio karių kapinėse šalia kitų Antrajame pasauliniame kare žuvusių SSRS karių ${ }^{42}$.

Kaip ir netoliese, vos už kelių šimtų metrų nuo Arsenalo g. 3, aptikti palaidoti vokiečių ir SSRS kariai, prie Neries palaidoti kariai yra žuvę 1944 m. liepos mènesị. Kapaviečių tankis tarp Vilniaus pilių komplekso ir Neries liudija, kad šioje vietoje vyko gana atkaklūs susiremimai. Idomu, kad visiškai šalia, dabartinés Lietuvos mokslų akademijos Vrublevskių bibliotekos pastate, nuo $1944 \mathrm{~m}$. liepos 13 d. buvo ịsikūręs SSRS kariuomenès III Baltarusijos fronto štabas, kuris čia rezidavo iki spalio mènesio ${ }^{43}$. Nors karių kapai Neries pakrantèje buvo vos už keliasdešimties metrų nuo štabo, palaikai nebuvo tinkamai perlaidoti, o sovietmečiu apskritai užmiršti.

\subsection{Bazilijonų vienuolyno kiemas \\ (Aušros Vartų g. 7 - Arklių g. 18)}

Antrojo pasaulinio karo Vokietijos karių kapavietė. 2006 m. archeologas Tauras Poška tęsè $2005 \mathrm{~m}$. pradètus tyrimus Bazilijonų vienuolyno komplekse $^{44}$. Jo pietvakarinèje dalyje buvo aptiktas grupinis kapas ir jame

${ }^{42}$ Gendrènas G., Ožalas E. Vilnius 2002. Karaliaus Mindaugo tilto prieigos. Žvalgomieji archeologiniai tyrimai. Ataskaita. I dalis. Karaliaus Mindaugo tilto atramos. Nacionalinio muziejaus Lietuvos Didžiosios Kunigaikštystės Valdovų rūmų archyvas, b. 425, p. 28-31; Gendrẻnas G., Ožalas E. Žvalgomieji archeologiniai tyrimai Vilniuje, statomo Karaliaus Mindaugo tilto prieigose // Archeologiniai tyrinèjimai Lietuvoje 2002 metais. Vilnius, 2005, p. 185.

${ }^{43}$ Lietuvos TSR istorijos ir kultūros sąvadas. 1. Vilnius. Vilnius, 1988, p. 390.

${ }^{44}$ Poška T. Bazilijonų vienuolynas Vilniuje, Aušros Vartų g. 7 - Arklių g. 18 // Archeologiniai tyrinėjimai Lietuvoje 2006 metais. Vilnius, 2007, p. 251-253. 


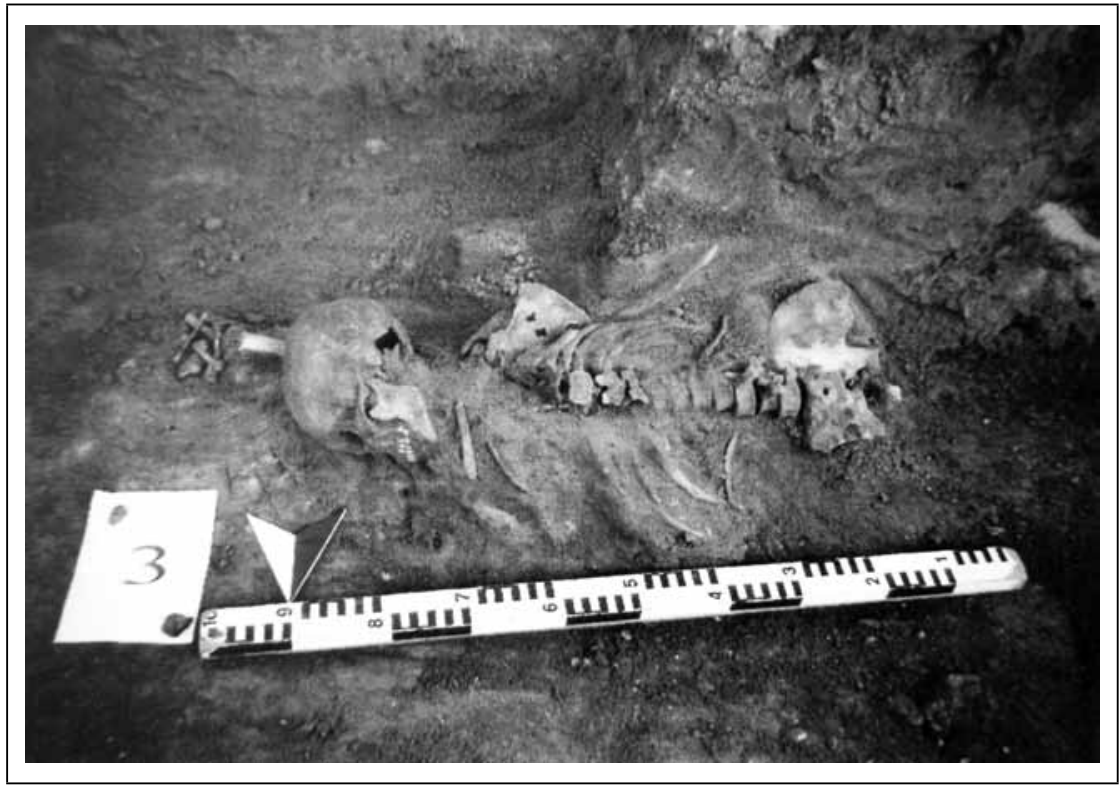

4 pav. Antrojo pasaulinio karo vokiečių karių grupinè kapavietė,

aptikta Bazilijonų vienuolyno kieme. Poška T. Aušros Vartu g. 7 / Arkliu g. 18, Vilniuje, archeologiniu tyrinèjimu $2006 \mathrm{~m}$. ataskaita. ARMA, b. 489A

identifikuoti 15 asmenų palaikai. Be to, suardytoje kapavietės dalyje rasti ne mažiau kaip aštuonių asmenų palaikų fragmentai ${ }^{45}$. Dalis kapavietės apardyta XX a. antroje pusèje čia atliekant žemès kasimo darbus. Palaikai buvo sumesti ị maždaug 2,7x3,4x1,7 m dydžio duobę, galimai išmuštą bombos. Tyrimų vietoje aptikta karinių uniformų fragmentų, medicininiai ịtvarai, medicininè „antis“ leido teigti, kad duobeje yra sumesti Antrojo pasaulinio karo pabaigoje ligoninejje gydytų ir sovietų kariuomenès sušaudytų vokiečių karių palaikai ${ }^{46}$.

Antropologinių tyrimų duomenys liudija, kad duobeje palaidoti

45 Jankauskas R., Barkus A., Urbanavičius A. Preliminarūs 2006 m. archeologinių kasinėjimų antropologinès medžiagos tyrimų rezultatai // Archeologiniai tyrinèjimai Lietuvoje 2006 metais. Vilnius, 2007, p. 534-535.

46 Poška T. Aušros Vartų g. 7 / Arklių g. 18 Vilniuje, archeologinių tyrinèjimų 2006 m. ataskaita. ARMA, b. 489A; Poška T. Bazilijonų vienuolynas Vilniuje, Aušros Vartų g. 7 - Arklių g. 18 // Archeologiniai tyrinejjimai Lietuvoje 2006 metais. Vilnius, 2007, p. $252-253$. 
beveik vien vyrai (kapai Nr. 1-14, nenumeruotas kapas ir 7 iš mažiausiai 8 palaikų fragmentų, aptiktų suardytoje kapavietes dalyje). Žuvusiųjų amžius - nuo 18 iki 45-50 m. (tačiau daugelis buvo ne vyresni kaip $35 \mathrm{~m}$.). Kai kuriuose skeletuose ir jų fragmentuose pastebèta kovinių sužalojimų pėdsakų - įvairių kaulų lūžių, kauluose ịstrigusių geležinių svetimkūnių (skeveldrų). Aptikta šautinių sužalojimų pẻdsakų. Itin iškalbingas sužalojimas pastebètas palaikuose Nr. 8 (20-30 m. vyro): kaktoje apie $2 \mathrm{~cm}$ virš tarpakio aiški kulkos įejjimo, o pakauškaulio žvyno kairèje pusèje - kulkos išèjimo anga ${ }^{47}$.

Archeologo T. Poškos iškelta versija, kad ị duobę buvo sumesti Antrojo pasaulinio karo pabaigoje sušaudytų karo ligoninëje gulëjusių vokiečių karių kūnai, visiškai ịtikinama, ypač atsižvelgiant ị pastebètus sužalojimus (šūvio i̇ galvą ir pan.). Tokią interpretaciją paremia kapavietès pobūdis: palaikai sumesti bet kaip, nepaisant elementarios pagarbos žuvusiesiems. Lyg pasityčiojant tarp palaikų įmesta ir ligoninès „antelë“ - basonas. Tai liudija aiškų karių, pribaigusių šiuos ligonius ir sužeistuosius, cinizmą.

Tai, kad Bazilijonų vienuolyno, kuriame $1944 \mathrm{~m}$. vasarą buvo karo ligoniné, teritorijoje sovietų kariai šaudè žmonès, terorizavo belaisvius ir medicinos personalą (apiplěšinèjo sužeistuosius, belaisvius, prievartavo medicinos seseris), liudija ir tuo metu čia buvę, išgyvenę ir po karo savo atsiminimus parašę Vermachto kariai Oigenas Hinenas ir Horstas Kolbergas ${ }^{48}$.

Bazilijonų vienuolyno kieme aptikti vokiečių karių palaikai buvo perlaidoti vokiečių karių kapinėse Vingio parke ${ }^{49}$. Vokiečių karių kapų globos tautinès sajungos atstovams perlaidoti buvo perduoti devyniolikos asmenu palaikai. Taip pat perduoti greta palaikų rasti daiktai - aštuoni kario identifikavimo žetonai, vienas medalionas, vienas vestuvinis žiedas, vienas žiedas (signetè), dvi monetos (5 ir 10 pfenigų nominalo ${ }^{50}$.

47 Jankauskas R., Barkus A., Urbanavičius A. Preliminarūs 2006 m. archeologinių kasinejjimų antropologinès medžiagos tyrimų rezultatai // Archeologiniai tyrinèjimai Lietuvoje 2006 metais. Vilnius, 2007, p. 534-535.

48 Oigeno Hinneno ir Horsto Kolbergo prisiminimai. Gintauto Širono asmeninis archyvas.

49 Poška T. Aušros Vartų g. 7 / Arklių g. 18, Vilniuje, archeologinių tyrinejjimų 2006 m. ataskaita. ARMA, b. 489A, p. 13.

50 Volksbund Deutsche Kriegsgräberfürsorge e.V. Umbettungsbericht. Vilnius, BasiliusKloster, Aušros vartų 7-Arklių Str. 18. 20.06.-05.07.2006. Vergebene U-Nr.: 34-52 (V̌̌t Kultūros vertybiu globos tarnybos archyvas). 


\subsection{S. Moniuškos skveras (Šv. Ignoto g. 5)}

Antrojo pasaulinio karo Vokietijos karių kapavietė. S. Moniuškos skvere 2003 m. archeologè Daiva Luchtanienè atliko archeologinius žvalgymus $120 \mathrm{~m}^{2}$ plote. Prie Benediktinių vienuolyno tvoros, maždaug $60 \mathrm{~cm}$ gylyje, 2,2x1,2 m dydžio duobẻje, buvo aptikti keturių asmenų palaikai. Iš šalia palaikų rastų kario identifikavimo žetonų nustatyta, kad čia palaidoti Antrojo pasaulinio karo metais žuvę vokiečių kariai. Kapavietejje taip pat rasta sagų, perpečių, diržų fragmentų, šovinių, šaukšto, šakutès, metalinès dèžutès liekanų, spèjamo antpečio fragmentas. Palaikai perduoti Vokiečių karių kapų globos tautinès sąjungos ekshumuotojų grupès Lietuvoje vadovui Manfredui Drobei ${ }^{51}$.

Buvo atlikti rastų mirusiųų palaikų antropologiniai tyrimai (autoriai - Rimantas Jankauskas, Arūnas Barkus, Agnius Urbanavičius). Visų keturių mirusiųjų skeletai visiškai išlikę. Palaikai Nr. 1 priklause 30-40 m., 170-175 cm ūgio vyrui. Konstatuota, kad kaukole iš dalies suardyta, pastebètas veido dešiniosios pusès perimortalinis sužalojimas (galèjo būti kovinè trauma). Palaikai Nr. 2 priklausè 25-30 m., 165-175 cm ùgio vyrui. Fiksuoti sužalojimų pèdsakai: dešiniojo šlaunikaulio proksimaliniogaloskeveldrinis lūžis (pe- rimortalinis) ir abiejų kairiosios blauzdos kaulų proksimalinių dalių skeveldriniai lùžiai (galèjo būti kovinè trauma). Palaikai Nr. 3

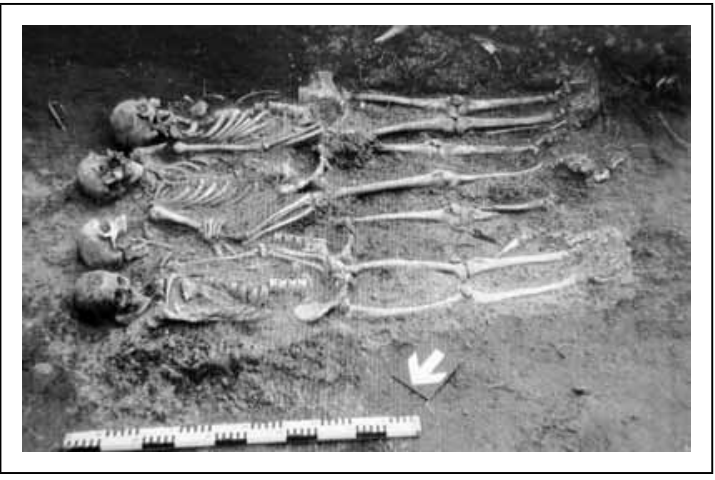

5 pav. Antrojo pasaulinio karo vokiečių karių grupinè kapavietė, aptikta Šv. Ignoto g. 5. D. Luchtaniené. Archeologiniu žvalgymu Šv. Ignoto g. 5, Vilniuje, 2003 metais rezultatai

${ }^{51}$ D. Luchtanienė. Archeologinių žvalgymų Šv. Ignoto g. 5, Vilniuje, 2003 metais rezultatai. Isegta $\mathfrak{i}$ bendra ataskaitą: Žukovskis R. Archeologinių žvalgymų Vilniaus senojo miesto vietos su priemiesčiais (A1610K) bei urbanistikos paminklo teritorijoje (UV-69), Vilniaus m. 2003 metais ataskaita. LII R b. 4172, p. 27-33. 
yra 30-35 m., 175-180 cm ūgio vyro. Palaikai Nr. 4 - jauniausio kario. Jam tebuvo 20-25 m., ūgis - 175-180 cm. Palaikuose Nr. 3 ir Nr. 4 akivaizdžių sužalojimų pẻdsakų taip pat nepastebèta ${ }^{52}$. Veikiausiai kulkos arba skeveldros kliudè paskutinių dviejų karių tik minkštuosius audinius.

\subsection{Latako g. ir Pilies g. kampas}

\section{Spėjama Pirmojo arba Antrojo pasaulinio karo Vokietijos karių} kapavietė. Latako g. 2 1980-1981 m. vykusių archeologinių tyrimų metu buvo rasta XV-XVI a. datuojamų kapų. Tyrimams vadovavo archeologas Gediminas Gendrènas ${ }^{53}$. S. Sarcevičiaus sudarytoje Vilniaus mieste archeologinių tyrimų metu rastų palaidojimų suvestinèje lenteleje nurodyta, kad čia aptikta ir Pirmojo pasaulinio karo vokiečių karių kapų ${ }^{54}$. Tačiau šis teiginys kelia labai didelių abejonių. Pirmojo pasaulinio karo metais Vokietijos kariuomene įžengè ị Vilnių be mūšių, o savo mirusiuosius laidojo karių kapinèse Antakalnyje ir dabartiniame Vingio parke. Archeologinių tyrimų ataskaitoje konkrečios informacijos apie rastus Pirmojo pasaulinio karo laikotarpio kapus nèra. Tyrimus atlikusio archeologo Gedimino Gendrèno liudijimu, tyrimų metu buvo atkasti kelių palaidotų žmonių kojų kaulai, ant kurių išlikę geros kokybės kaustyti batai (veikiausiai vokiški). Tyrëjas nusprendè neinformuoti sovietinių valdžios institucijų apie radinị, nes to meto archeologų patirtis liudijo, kad, apie tai pranešus, palaikai bus paimti ir dings be žinios. Palaikai, dar visiškai neatkasti, vèl buvo užpilti žemėmis ir palikti ${ }^{55}$. Manytume, kad Latako ir Pilies gatvių kampe veikiausiai buvo rasti ne Pirmojo, o Antrojo pasaulinio karo Vokietijos kariuomenès karių palaikai.

52 Jankauskas R., Barkus A., Urbanavičius A. Preliminarūs 2003 m. archeologinių kasinejjimų antropologinès medžiagos tyrimų rezultatai // Archeologiniai tyrinèjimai Lietuvoje 2003 metais. Vilnius, 2005, p. 306.

53 Gendrėnas G. Vilnius, 1980-1981 m. 160 vietų Dailès instituto bendrabutis Latako g-vejje. Archeologiniai tyrimai. Ataskaita. Plotas Nr.1-3. LIIR, f. 1, b.1606c-d.

54 Vilniaus m. archeologinių tyrimų metu aptiktų palaidojimų suvestinė // Vilniaus archeologijos atlasas [kompaktinè plokštelè]. Sud. G. Vaitkevičius, O. Vailionienè. Vilnius, 2006; Interneto prieiga: http://www.istorija.lt/html/miestu.html [tikrinta 2012.11.15]

55 G. Gendrèno žodinè informacija (2012 m. lapkričio 22 d.). 


\subsection{Daukšos g. 5}

Antrojo pasaulinio karo Vokietijos karių kapavietė. 2008 m. archeologas Saulius Sarcevičius atliko archeologinius žvalgymus Lapų ir M. Daukšos gatvèse, kur buvo kasamos telekomunikacijų trasos. Daukšos g. 5 aptikti suardyti žmonių palaikai ir greta jų buvę keli odinių batų fragmentai, trys šoviniai ir kario identifikavimo žetonas. Manoma, kad rasti kapai yra vokiečių karių, žuvusiųjų per Antrąji pasaulinị karą ${ }^{56}$. Šių tyrimų atskaita dar neparengta. Palaikai buvo perduoti Vokiečiu karių kapų globos tautinès sajungos ekshumuotojų grupès atstovams ir perlaidoti vokiečių karių kapinèse Vingio parke ${ }^{57}$.

\section{LUKIŠKĖS}

\section{1. Šv. Jokūbo ir Pilypo bažnyčios šventorius}

Antrojo pasaulinio karo Vokietijos karių kapavietė. 1998 m. buvo atliekami žvalgomieji archeologiniai tyrimai ir archeologiniai žvalgymai (vadovè - Daiva Luchtanienè) Šv. Jokūbo ir Pilypo bažnyčios šventoriuje. Ištirta 11 šurfų, žvalgytos požeminių komunikacijų tranšèjų kasimo vietos. Tyrimų metu rasta suardytų žmonių palaikų. Didžioji dalis jų priskirta čia XVI-XVII a. buvusioms beturčių kapinėms, o šurfe Nr. 4 rasti individualūs radiniai aiškiai yra XX a. Čia rasta šovinių ir vokiškos dujokaukès liekanų ${ }^{58}$. Atlikus palaikų antropologinius tyrimus paaiškejjo, kad kai kurie kaulai priklauso XX a. gyvenusiems žmonèms (tarp tranšèjose nuo šurfo Nr. 4 iki šurfo Nr. 5, nuo šurfo Nr. 5 iki šurfo Nr. 6 rastų kaulu buvo balto metalo ir porceliano dantų tiltelis $)^{59}$. D. Luchtanienè iškèle prielaidą, kad kai kuriose šventoriaus vietose gali būti palaidoti šalia

56 S. Sarcevičiaus žodinè informacija (2012 m. lapkričio 15 d.); Mažai informatyvūs archeologiniai tyrinejjimai (sud. Eglè Marcinkevičiūtè) // Archeologiniai tyrinejjimai Lietuvoje 2008 metais. Vilnius, 2009, p. 564.

57 S. Natkevičiaus žodinè informacija (2012 m. lapkričio 22 d.).

58 Luchtanienė D. Žvalgomieji archeologiniai tyrimai Vilniuje, Šv. Jokūbo ir Pilypo bažnyčios aplinkoje, 1998 m. Ataskaita. LIIA, f. 1, b. 3224, p. 4-6, 10-11.

59 Jankauskas R. Palaikų iš Vilniaus, Lukiškių a. 10, (1998 m.) antropologinio tyrimo rezultatai. Idetiniai lapai ataskaitoje: Luchtanienė $\mathbf{D}$. Žvalgomieji archeologiniai tyrimai Vilniuje, Šv. Jokūbo ir Pilypo bažnyčios aplinkoje, 1998 m. Ataskaita. LIIA, f. 1, b. 3224, p. 28-29. 
bažnyčios veikusioje karo ligoninèje mirę arba mūšiuose žuvę vokiečių kariai $^{60}$. Ši versija labai ittikima: yra žinoma, kad $1944 \mathrm{~m}$. liepos 9-10 d. vienas paskutinių Vokietijos kariuomenès atsparos punktų Vilniaus mieste buvo būtent šalia Lukiškių aikštès ${ }^{61}$.

\subsection{Rotundo g. $4 \mathrm{~A}$}

XIX a. Rusijos imperijos karių ir kitụ asmenų kapavietè. $2003 \mathrm{~m}$. tiesiant elektros kabelį A. Rotundo g., ties sklypu Nr. 4 buvo iškasta $0,8 \times 1,8 \mathrm{~m}$ dydžio, iki $1,45 \mathrm{~m}$ gylio duobė. Aptikta paskirų žmonių kaulu iš suardytų nežinomų kapinaičių. Radinių neaptikta ${ }^{62}$. Ištyrus rastus pavienius žmonių kaulus paaiškejjo, kad jie visi yra $25-40$ metų vyrų ${ }^{63}$.

$2006 \mathrm{~m}$. birželio mèn. sklype A. Rotundo g. 4A buvo atlikti žvalgomieji archeologiniai tyrimai. Iškasti 5 archeologiniai šurfai, tyrinètas $20 \mathrm{~m}^{2}$ dydžio plotas. Sklypo pietinėje dalyje kastame šurfe Nr. 5 aptiktas griautinis kapas. Padaryta išvada, kad sklype prieš numatomas statybas būtina atlikti nuodugnius archeologinius tyrimus. Jų metu kasinètas $1787 \mathrm{~m}^{2}$ dydžio plotas. Aptiktas 1,0-1,5 m storio kultūrinio sluoksnio horizontas, susiformavęs XIX-XX a. Jis buvo nukastas mechanizuotai. Sklypo centrinëje ir pietineje dalyse, smèlio ir priemolio įžemyje, pastebèti stačiakampiai kapų duobių kontūrai. Iš viso tyrinèti 56 kapai. Juose rasti 8 asmenų skeletai. 22 kapuose aptikta nuo 2 iki 5 skeletų. Mirusieji palaidoti vienas šalia kito arba keliais lygiais. 80 asmenų palaikai galvomis orientuoti vakarų arba šiaurės vakarų kryptimi, 5 asmenų - rytų ir pietryčių kryptimis. Mirusieji palaidoti aukštielninki, ištiestomis kojomis; rankos sudètos ant krūtinès arba juosmens ir dubens srityje. Sprendžiant iš kapuose

${ }^{60}$ Luchtanienė D. Žvalgomieji archeologiniai tyrimai Vilniuje, Šv. Jokūbo ir Pilypo bažnyčios aplinkoje, 1998 m. Ataskaita. LIIA, f. 1, b. 3224, p. 10.

${ }^{61}$ Kovos dèl Vilniaus $1944 \mathrm{~m}$. liepą. Interneto prieiga: http://www.antraspasaulinis.net/ e107_plugins/content/content.php?content.1161 [tikrinta 2012-11-16]

62 Žukovskis R. Archeologinių žvalgymų Vilniaus senojo miesto vietos su priemiesčiais (A1610K) bei urbanistikos paminklo teritorijoje (UV-69) Vilniaus m. 2003 metais ataskaita. Vilnius, 2004. LIIA, f. 1, b. 4172, p. 129.

${ }^{63}$ Barkus A. Palaikų, rastų Vilniuje, Rotundo g., kasant tranšèją elektros kabeliui, antropologinio tyrimo ataskaita. İdetinis lapas ataskaitoje: Žukovskis R., Archeologinių žvalgymų Vilniaus senojo miesto vietos su priemiesčiais (A1610K) bei urbanistikos paminklo teritorijoje (UV-69) Vilniaus m. 2003 metais ataskaita. Vilnius, 2004. LIIA, f. 1, b. 4172, p. 130. 
aptiktų sutrūnijusios medienos likučių, o aštuoniais atvejais - ir iš rastų geležinių vinių, mirusieji buvo palaidoti karstuose. Aštuoniuose kapuose mirusiųjų kaklo ir krūtinès srityje rasti stačiatikių variniai kryželiai. Dešimtyje kapų rasta nuo 1-2 iki 16-26 vnt. varinių sagų. Nors jokio piešinio jose nepastebèta, manoma, kad tai XIX a. Rusijos kariuomenès uniformų sagos ${ }^{64}$. Aptiktų palaikų antropologinius tyrimus atliko Arūnas Barkus. Tyrimų duomenimis, dauguma mirusiųjų (72 asmenys) vyrai. Daugiau negu pusè jų (48 asmenys) buvo jauni ir vidutinio amžiaus: 5 asmenys - 16-20 metų; 15 asmenų - 20-30 metų; 10 asmenų - 25-35 metų; 18 asmenų - 30-40 metų. Penkiais atvejais palaidotų vyrų amžius nenustatytas. Iš likusių palaidojimų 2 skeletai buvo moterų, 8 - vaikų nuo naujagimio iki 8-10 metų. Vienu atveju aptikta tik suaugusio asmens kojų kaulų dalis; lytis neaiški. Be to, aptikta 72 pavieniai kaulai iš suardytų kapų. Nustatytos kai kurios įdomesnès patologijos. Kapas Nr. 12, skeletas Nr. 2: 30-40 metų vyrui buvo amputuota dešinioji koja, gijimo žymių nèra (vadinasi, netrukus po amputacijos žmogus mirè). Kapas Nr. 21, skeletas Nr. 2: 25-30 metų vyras palaidotas po autopsijos - buvo nupjautas kaukolès skliautas. Autopsija taip pat užfiksuota kape Nr. 43 palaidoto 35-45 metų vyro palaikuose. Kapas Nr. 22: vyresnio nei 30 metų vyro palaikuose užfiksuoti sugiję abiejų kairès rankos dilbio kaulų lūžiai. Kapas Nr. 36, skeletas Nr. 2: jaunesnio nei 30 metų vyro palaikuose užfiksuotas sugijęs kairiojo šlaunikaulio lūžis ${ }^{65}$. Po tyrimų palaikai buvo perlaidoti Šv. Pranciškaus ir Bernardo bažnyčios rūsiuose.

Remdamasis archeologinių tyrimų rezultatais, taip pat atsižvelgdamas ì antropologinès analizès išvadą, jog daugumą mirusiųjų sudarè 20-40 metų vyrai, R. Žukovskis padarè išvadą, kad šioje vietoje yra palaidoti carinès Rusijos kariuomenès kariai. Mirtinų sužeidimų osteologinès analizès tyrimų duomenys neleido ịžvelgti, todèl labiausiai tikètina, kad mirties priežastis galèjo būti užkrečiamosios ligos, pavyzdžiui, XIX a. pirmoje pusejje siautusi choleros epidemija ${ }^{66}$. Archeologinių tyrimų

64 Žukovskis R. A. Rotundo g. 4A, Vilniuje, 2006 m. vykdytų archeologinių tyrinèjimų ataskaita. LIIA, f. 1, b. 4720, p. 24.

65 Barkus A. Palaikų, rastų Vilniuje, Rotundo g., 2006 m. antropologinio tyrimo ataskaita. Idetiniai lapai ataskaitoje: Žukovskis R. A. Rotundo g. 4A, Vilniuje, 2006 m. vykdytų archeologinių tyrinejjimų ataskaita. LIIA, f. 1, b. 4720, p. 80-84.

66 Žukovskis R. A. Rotundo g. 4A, Vilniuje, 2006 m. vykdytų archeologinių tyrinèjimų ataskaita. LIIA, f. 1, b. 4720, p. 24. 
išvados dera su istorinių tyrimų duomenimis. Yra žinoma, kad šioje vietoje buvo laidojamos $1831 \mathrm{~m} ., 1848 \mathrm{~m}$. ir $1853 \mathrm{~m}$. kilusių epidemijų aukos. 1831 m. čia laidoti Rusijos kariuomenès Vilniaus igulos kariai, o vèliau - ir neturtingi miestiečiai, kūdikiai bei Šv. Jokūbo ligoninèje mirę pacientai. Kapinèse laidota iki $1854 \mathrm{~m}$. Šios kapinès buvo labai apleistos, net neaptvertos ${ }^{67}$.

\section{NAUJAMIESTIS}

\subsection{Kauno g. ir Švitrigailos g. sankirta}

Spëjama masinè kapavietė. 2005 m. archeologas S. Sarcevičius atliko archeologinius žvalgymus Kauno ir Švitrigailos gatvių sankirtoje. Statybos darbų metu čia buvo rasta žmonių kaulų be jokių ịkapių. Jų chronologija neaiški ${ }^{68}$. S. Sarcevičius neatmeta galimybès, kad šioje vietoje gali būti aptikta apardyta masinè kapavietè, galbūt karių kapai. Žmonių palaikų radimo vietoje statybos darbai buvo sustabdyti, toliau archeologiniu tyrimų nevyko. Rastus žmonių kaulus paèmé policijos pareigūnai ${ }^{69}$.

\subsection{Mindaugo $\mathrm{g}$.}

1831 m. sukilimo laikų Rusijos karių kapavietė. 2000 m. sklype Mindaugo g., tarp namų Nr. 14 ir Nr. 16, buvo vykdomi archeologiniai tyrimai (vadovas - Vidas Daminaitis). Ištirtas apie $1360 \mathrm{~m}^{2}$ plotas, aptiktos iki tol buvusios nežinomos kapinès. Surasti 44 nesuardyti ir iš dalies apardyti kapai. Daugelis mirusiųjų palaidoti duobėse po vieną, tačiau pasitaikè ir grupinių kapų, kuriuose rasti dviejų, trijų, keturių asmenų palaikai. Dauguma mirusiųjų buvo palaidoti mediniuose karstuose. Beveik visi palaikai buvo apibarstyti kalkėmis. Tai liudija, kad palaikai buvo dezinfekuojami, o čia palaidoti žmonès veikiausiai mirè nuo užkrečiamosios ligos. Šalia palaikų buvo rasti septyni stačiatikių kryželiai ir du medalionai

67 Jogèla V., Meilus E., Pugačiauskas V. Lukiškès: nuo priemiesčio iki centro (XV-XX a.). Vilnius, 2008, p. 148-152.

68 Tyrinejjimai, nesuteikę vertingos archeologinès informacijos (sud. Eglè Marcinkevičiūtè) // Archeologiniai tyrinèjimai Lietuvoje 2005 metais. Vilnius, 2006 m., p. 481.

69 S. Sarcevičiaus žodinè informacija (2012 m. lapkričio 15 d.). 
su rusiškais rašmenimis ${ }^{70}$. Atlikus palaikų antropologinę analizę (autorius - R. Jankauskas) nustatyta, kad tirtame plote buvo palaidota apie 70 asmenų. Palaidotųjų lytis ir amžiaus struktūra aiškiai skiriasi nuo iprastinių kapinių: palaidoti išimtinai vyrai, daugiausia jauni (tik 7 asmenys buvo vyresni nei 40 metų). Anot R. Jankausko, galima įtarti, kad tai specifinè socialinè grupė (pvz., kariai), mirę nuo kokios nors ūmios (galbūt infekcinès) ligos, kuri nepaliko būdingų pažeidimų kauluose. Tačiau panašu, kad bent kai kurie iš palaidotųju sirgo ilgesnị laiką (vieną dvi savaites). Tai liudytų ūmaus ir poūmio sisteminio periostito pédsakai bent trylikos individų kauluose. Bent du asmenys sirgo poūmiu pleuritu (nespecifiniu arba tuber-

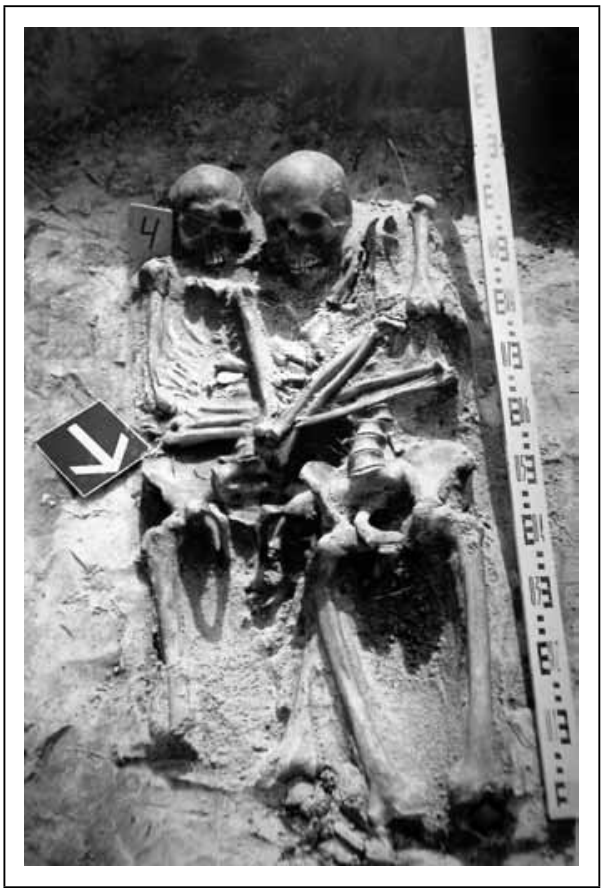

6 pav. Dviejų asmenų kapas, rastas tiriant XIX a. Rusijos karių kapavietę Mindaugo gatveje. Daminaitis V. 2000 m. Vilniuje, sklype Mindaugo gatveje, tarp namu Nr. 14 ir Nr. 16, vykdytu archeologiniu tyrimu ataskaita, f. $1, b .3718$ kuliozinès kilmès). R. Jankauskas taip pat atkreipé dèmesị ị kapuose Nr. 26 ir Nr. 35 palaidotų asmenų slankstelių patologiją, būdingą bruceliozei. Šia liga užsikrečiama geriant sergančių ožkų pieną. Lietuvoje bruceliozė reta. Ši liga labiau būdinga Europos pietiniams regionams. Gali būti, kad šie žmonès brucelioze užsikrètè ne Lietuvoje, o atkeliavo jau užsikrètę.

70 Daminaitis V. 2000 m. Vilniuje, sklype Mindaugo gatvejje tarp namų Nr. 14 ir Nr. 16, vykdytų archeologinių tyrimų ataskaita, f. 1, b. 3718; Daminaitis V. Tyrinèjimai Vilniuje, Bonifratrų vienuolyne ir Mindaugo gatvejje // Archeologiniai tyrinejjimai Lietuvoje 2000 metais. Vilnius, 2002, p. 162-163. 
Taip pat pastebėta traumų pėdsakų (kape Nr. 3 - sugijęs kairiojo raktikaulio lūžis; kape Nr. 4 - sugijusi muštinẻ kaktikaulio žaizda; kape Nr. 27 sugijęs kairiojo žastikaulio lūžis; kape Nr. 32 - sugijusi kairès plaštakos trauma; kape Nr. 36 - sugijusi muštinė žaizda ties kairiuoju kaktos gumburu; kape Nr. 37 - sugijęs nosikaulio lūžis) $)^{71}$. V. Daminaitis iškèle prielaidą, kad šioje kapavieteje yra palaidoti $1831 \mathrm{~m}$. Lietuvoje siautusios choleros epidemijos metu mirę Rusijos kariuomenès kariai. $1831 \mathrm{~m}$. balandžio $7 \mathrm{~d}$. feldmaršalas J. Dibičas įsakè 1-osios ulonų divizijos vadui generolui leitenantui kunigaikščiui S. Chilkovui žygiuoti į Lietuvą. Balandžio $11 \mathrm{~d}$. S. Chilkovas su 1-osios ulonų divizijos brigada ir 12-osios artilerijos brigados viena kuopa išžygiavo iš Tiraspolio (dab. Padniestré, Moldova) i Lietuvą. Šiuose daliniuose gegužès pradžioje ėmė plisti choleros epidemija ${ }^{72}$. Labai tikètina, kad būtent Rusijos kariai ir atnešè ị Lietuvą choleros epidemiją. Pasiekę Vilnių kariai sirgo ir masiškai mirè. Viena iš jų laidojimui parinktų vietų, sprendžiant iš aptiktos kapavietès, buvo iš grafo Liudviko Pliaterio konfiskuotos žemès dabartinès Mindaugo gatvès rajone. Panašu, kad dalis šių kapinių yra atsidūrusios ir po Mindaugo gatvès važiuojamąja dalimi, driekiasi link prekybos centro „Maxima" ${ }^{\text {“73 }}$.

\subsection{Z. Sierakausko g. 15}

XIX a. Rusijos karių (?) ir kitų asmenų palaikų antrinio palaidojimo vieta. $2001 \mathrm{~m}$. sklype Z. Sierakausko g. 15 pradejus statybos darbus ir atkasus demontuojamas inžinerines komunikacijas, rasta paskiru žmonių kaulų, kurie buvo suversti ị komunikacijoms iškastas tranšejjas. Atlikus sklypo žvalgomuosius archeologinius tyrimus (tirti trys $2 \times 2 \mathrm{~m}$ dydžio žvalgomieji šurfai) konstatuota, kad šioje vietoje nebuvo laidota ${ }^{74}$. Todèl padaryta išvada, kad žmonių kaulai ị sklypą Z. Sierakausko g. 15

71 Jankauskas R. Palaikų iš Mindaugo g. (Vilnius, 2000 m.) antropologinio tyrimo rezultatai. Idètiniai lapai ataskaitoje: Daminaitis V. 2000 m. Vilniuje, sklype Mindaugo gatveje tarp namų Nr. 14 ir Nr. 16, vykdytų archeologinių tyrimų ataskaita, f. 1, b. 3718, p. 32-40.

72 Sliesoriūnas F. 1830-1831 metų sukilimas Lietuvoje. Vilnius, 1974, p. 158, 203.

73 Daminaitis V. 2000 m. Vilniuje, sklype Mindaugo gatvèje tarp namų Nr. 14 ir Nr. 16, vykdytų archeologinių tyrimų ataskaita, f. 1, b. 3718, p. 23-24.

${ }^{74}$ Katalynas K. Žvalgomųjų archeologinių tyrimų ir archeologinių žvalgymų $2001 \mathrm{~m}$. Vilniuje, Z. Sierakausko g. Nr. 15, ataskaita. Vilnius, 2002 m. LIIA, f. 1, b. 3718. 
galejo patekti iš statybų metu ardomų kalvos papèdèje XIX a. buvusių „Pragarèlio [dabartinès Pakalnès gatvès aplinkos istorinis toponimas] našlaičių kapinių“, kuriose iš pradžių (nuo $1831 \mathrm{~m}$.) buvo laidojami choleros epidemijos metu mirę Vilniaus igulos kariai, vèliau - našlaičiai ir ligoniai iš Šv. Jokūbo ir Pilypo bažnyčios prieglaudos. Kapinès $1854 \mathrm{~m}$. minimos kaip apleistos, netvarkomos, neturinčios netgi tvoros ${ }^{75}$. Tikètina, kad jas ardyti pradèta $1860 \mathrm{~m}$., statant Vilhelmo Šopeno alaus daryklą greta dabartinès Pakalnès gatvès. Perkèlus palaikus iš „Pragarèlio našlaičių kapinių“ ì dabartinę Sierakausko gatvę, atsirado antrinė laidojimo vieta.

Archeologo L. Girlevičiaus duomenimis, Z. Sierakausko g. 15 yra ir nesuardytų, neperlaidotų žmonių palaikų. 2001 ar 2002 m. rengdami laiptelius ì pastate esančią kavinę, statybininkai prie jo rytinio kampo aptiko nesuardytų žmonių palaikų. Kapai nebuvo atkasti iki galo ir vèl užpilti žemėmis, o statybinès konstrukcijos įrengtos taip, kad jų nepažeistų ${ }^{76}$.

\subsection{Vingio parkas}

Antrojo pasaulinio karo Vokietijos kario kapas. 2003 m. birželio mènesị Vingio parke esančiose vokiečių karių kapinèse kasant kapo duobes kitose vietose ekshumuotiems vokiečių karių palaikams perlaidoti, aptikti vieno Vokietijos kario palaikai ir šalia jo buvęs kario identifikavimo žetonas ${ }^{77}$.

\section{4. ŽVÉRYNAS}

\subsection{Traidenio g.}

Antrojo pasaulinio karo Vokietijos karių kapavietė. Istoriko Sakalo Natkevičiaus duomenimis, apie 1994 m. vykdant statybos darbus Traidenio gatveje, buvo aptikti trijų žmonių palaikai. Archeologinių tyrimų šioje vietoje nebuvo atlikta. Sprendžiant iš kapavieteje rastų radinių,

\footnotetext{
75 Jogèla V., Meilus E., Pugačiauskas V. Lukiškès: nuo priemiesčio iki centro (XV-XX a.). Vilnius, 2008, p. 150, 152.

76 L. Girlevičiaus žodinè informacija (2012 m. lapkričio 23 d.).

77 Volksbund Deutsche Kriegsgräberfürsorge e.V. Umbettungsbericht. Vingio - Park, Vilnius, 20.06.2003. Vergebene U-Nr.: 001 (Všl Kultūros vertybiu globos tarnybos archyvas).
} 
aprangos detalių, tai - Antrojo pasaulinio karo vokiečių karių kapai. Palaikai buvo surinkti ir saugomi Antakalnio kapinių koplyčioje, o vèliau perlaidoti šiose kapinèse ${ }^{78}$.

\section{5. ŽVEJAI}

\section{1. Žvejų g., Šv. Rapolo parapinès kapinès}

1992 m. gruodžio 2-3 d., vykdant Armijos Krajovos (Armia Krajowa, AK) karių perlaidojimą Rasų kapinèse, bandyta rasti 1944 m. liepos 13 d. Kriaučiūnų kaime, Vilniaus rajone, žuvusio ir tuo metu jau neveikiančiose Šv. Rapolo parapinėse kapinėse slapta perlaidoto AK kapitono Česlavo Grombčevskio (Czesław Grombczewski, slapyvardis - Jurand ${ }^{79}$ palaikus. Šv. Rapolo parapinès kapinès formaliai uždarytos $1866 \mathrm{~m} .{ }^{80}$ Didelè jų dalis suardyta po Antrojo pasaulinio karo greta Pirmosios elektrinès statant garažus. Kapo lokalizacija apytikslè, nustatyta pagal vieną mėgejjišką Č. Grombčevskio artimųjų darytą nuotrauką. Kasinėta tranšejų tinklu; darbus stebejo lenkų delegacijos narys archeologas prof. habil. dr. Jerzy's Kruppe ir Lietuvos Respublikos atstovas archeologas Kęstutis Katalynas. Rasti Č. Grombčevskio palaikų nepavyko. Rasų kapinėse įrengtas jo kenotafas (simbolinis kapas).

\footnotetext{
78 S. Natkevičiaus žodinè informacija (2012 m. lapkričio 22 d.).

79 Kapitonas Č. Grombčevskis (Czesław Grombczewski-Jurand) buvo AK Vilnijos I brigados, veikusios ị šiaurę ir šiaurès rytus nuo Vilniaus, karininkas. Vadovavo brigados avangardui žygiuojant nuo Maišiagalos link performavimo rajono greta Turgelių miestelio. Žuvo 1944-07-13 ryte nuo besitraukiančio iš Vilniaus vokiečių igulos kulkosvaidžio serijos, bandydamas su savo grupe stabdyti vokiečių prasiveržimą iš Raudonosios armijos apsupto Vilniaus. Šaltiniai: Korab-Żebryk R. Operacja wileńska AK. Warszawa, 1988, s. 386, 387; taip pat Romano Korab-Žebryko atsiminimai (jis buvo AK poručikas „Korab“, Č. Grombčevskio pavaldinys, dalyvavo mūšyje ir matè savo vado mirtį; taip pat dalyvavo Č. Grombčevskio palaikų paieškoje).

${ }^{80}$ Jogèla V., Meilus E., Pugačiauskas V. Lukiškès: nuo priemiesčio iki centro (XVXX a.). Vilnius, 2008, p. 148.
} 


\section{6. ŠNIPIŠKĖS}

\subsection{Kalvarijų g. pradžia (sunaikintas „Vilniaus kalnelis“)}

Spëjama 1812 m. karo Napoleono karių kapavietė. $1950 \mathrm{~m}$. statant naują Žaliąji tiltą karo metais susprogdinto tilto vietoje, dešiniajame Neries krante, Kalvarijų gatvès pradžioje buvo nuspręsta nukasti vadinamąji „Vilniaus kalnelį“. Šis kalnelis buvo sakrali vieta - čia stovèjo mūrinè koplytėlè su kryžių nešančio Kristaus skulptūra. A. H. Kirkoras spejjo, kad kalnelyje buvo laidojami kovų su kryžiuočiais metu žuvę žmonès ${ }^{81}$, o V. Zahorskis pateikè versiją, kad ten gali būti palaidoti Vilnių puolę

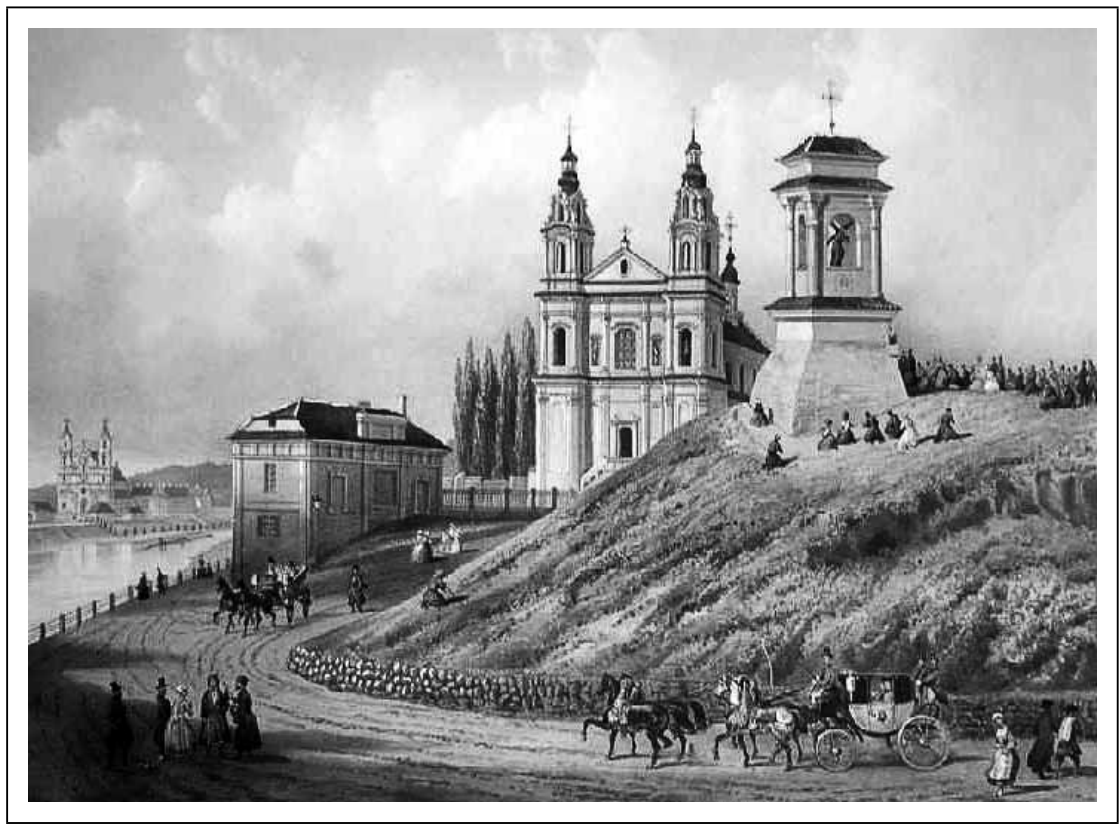

7 pav. Šnipiškių priemiestis XIX a. (dešinèje matyti „Vilniaus kalnelis“ spejama, sunaikinta $1812 \mathrm{~m}$. Napoleono armijos karių kapavietè). Iš Jono Kazimiero Vilčinskio „Vilniaus albumo“ („Album de Wilna“, Paris, 1848)

${ }^{81}$ Kirkor A. H. Przewodnik historyczny po Wilnie i jego okolicach. Wilno, 1880, s. 251; Kirkor A. H. Przewodnik po Wilnie i jego okolicach z wykazaniem najbliższych stacyj kolei żelaznych. Wilno, 1889, s. 247. 
kryžiuočiai arba $1710 \mathrm{~m}$. Vilniuje siautusio maro aukos ${ }^{82} .1950 \mathrm{~m}$. statant naują Žaliajji tiltą, anot archeologinius žvalgymus naikinamo archeologinio objekto vietoje atlikusio M. Černiausko, „kalnelis ir jame buvusis mürinis stulpas - koplytèle, kurie laiko bègyje ięjo ị istorija ir sudare jos neatskiriamą dali, vykdant socialistines statybas, turèjo užleisti vieta naujiems miesto ịrenginiamss ${ }^{\text {"83 }}$. Archeologams apie kalvelès naikinimą buvo pranešta, kai statybininkai jau buvo nukasę ketvirtadali „Vilniaus kalnelio". Vykdant archeologinius žvalgymus ir nedidelès apimties archeologinius tyrimus buvo ištirtas vienas geriau išlikęs kapas ir fiksuota dešimtys suardytų kapų. Rasta karstų liekanų, vinių, 1664 m. Jono Kazimiero moneta, „buržuazinès“ (suprask - tarpukario) Lenkijos karininko kardas su makštimi (tyrimų metu dingo), Didžiojo karo laikotarpio (veikiausiai turimas galvoje Pirmasis pasaulinis karas) rusiškas šautuvas (taip pat dingo). Remdamasis tyrimų duomenimis M. Černiauskas teigè, kad kalnelyje buvo XVII a. datuojamos kapinès, tačiau neatmetè versijos, jog čia galëjo būti ir bent pavienių Napoleono armijos karių kapų, su kuriais jis siejo tyrimų metu rastas sagas su liūtų atvaizdu ${ }^{84}$. M. Černiausko prielaida, kad kalnelyje galejjo būti laidojami ne tik miestiečiai, bet ir $1812 \mathrm{~m}$. karų dalyviai, gana ịtikinama. Greta buvusio kalnelio esančioje Šv. Rapolo bažnyčioje ir buvusiame jèzuitų vienuolyne $1812 \mathrm{~m}$. pabaigoje buvo prisiglaudę iš Rusijos besitraukiantys Napoleono kariuomenès 4-ojo korpuso likučiai ${ }^{85}$. Kareiviai nuplešè bažnyčios stogą, sugadino vargonus, altorius, sudegino suolus. Taip pat čia buvo ịrengtas ginklų sandèlis ${ }^{86}$. Tikètina, kad tam tikras skaičius sužeistų, iš bado ir šalčio mirusių karių galëjo būti palaidoti ir greta buvusiose senose vilniečiu kapinèse. Tačiau dèl to, kad sovietmečiu šis laidojimo paminklas buvo visiškai sunaikintas, šios versijos negalima nei patvirtinti, nei paneigti.

\footnotetext{
82 Zahorski W. Przewodnik po Wilnie. Wyd. 4. Wilno, 1927, s. 131-133.

83 Černiauskas M. Vilniaus kalnelio Dzeržinskio-Ukmergès gatvių sankryžoje stebejjimai-tyrinejjimai. LIIR, f. 1, b.13, p. 4.

${ }^{84}$ Černiauskas M. Vilniaus kalnelio Dzeržinskio-Ukmergès gatvių sankryžoje stebejjimai-tyrinejjimai. LIIR, f. 1, b.13, p. 5-12.

85 Pugačiauskas V. Napoleonas ir Vilnius: karinio gyvenimo kasdienybès bruožai. Vilnius, 2004, p. 100

86 Vilniaus bažnyčių ịrašai. T. 1. Sud. Wlodzimierz A., Ulčinaitė E. Vilnius, 2005, p. 283.
} 


\section{KAREIVIŠKĖS}

\subsection{S. Žukausko g.}

1812 m. karo Napoleono karių kapavietè. 2001 m. rudenį kasant tranšèją inžinerinėms komunikacijoms buvusio karinių pastatų komplekso, žinomo „Šiaurès miestelio“ pavadinimu, teritorijoje buvo rasta 1812 m. Napoleono kariuomenės karių masinè kapavietė. 2002 m. buvo

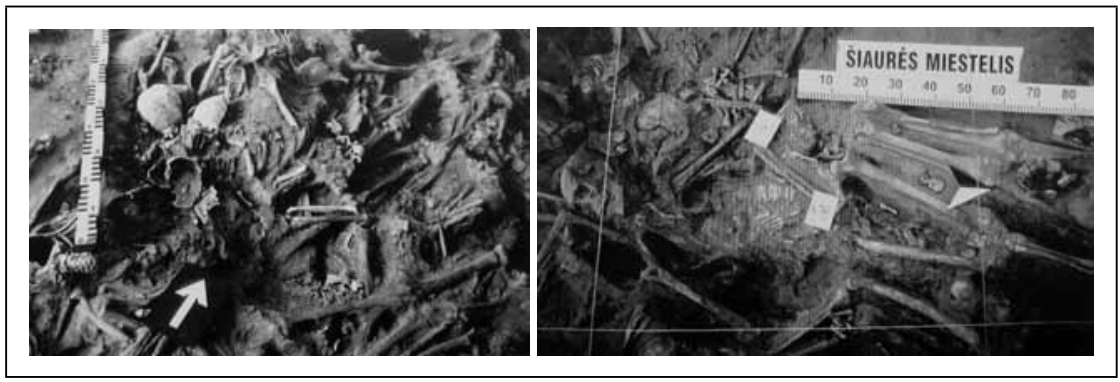

8-9 pav. Masinès $1812 \mathrm{~m}$. Napoleono armijos karių kapavietės Šiaurès miestelyje tyrimų fragmentai. Poškienè J. Masinès Napoleono armijos karių kapavietès Vilniuje,

Šiaurés miestelyje, Verkiu g. (dab. S. Žukausko g.), 2002 m. LIIR, f. 1, b. 3975

surengti plataus masto tyrimai, juos vykdè archeologų grupé: Albinas Kuncevičius (vadovas), Justina Poškienè, Tauras Poška, Linas Girlevičius. Antropologinius tyrimus atliko Rimanto Jankausko vadovaujama tyrèjų grupè, kurioje dirbo ir Marselio universiteto (Prancūzija) atstovai. Istorinius tyrimus atliko Virgilijus Pugačiauskas. Buvo ištirtas $600 \mathrm{~m}^{2}$ plotas, lauko sąlygomis identifikuota daugiau nei 600 individų. Atliekant išsamius antropologinius tyrimus Vilniaus universiteto antropologijos laboratorijoje nustatyta, kad kapavietejje buvo palaidoti ne mažiau kaip 2724 asmenys. Nustatyta, kad nuo sužeidimų, ligų ir šalčio mirę Napoleono kariuomenès kariai buvo užkasti tos pačios kariuomenės įrengtos gynybinès linijos atkarpoje (redute?). Mirusiųjų kūnai buvo sumesti vienas ant kito be jokios tvarkos ir kapavieteje gulejo įvairiomis pozomis (ant nugaros, pilvo, šono, kniūbsti ir pan.). Palaikų sluoksnis - iki 0,7 m storio. Greta palaikų rasta ir individualių radinių (daugiausia - uniformų sagų). Aptikta audinių (uniformų, kepurių likučių), batų liekanų, geležinių sagčių, kuprinių užsegimo detalių, virvučių. Iš asmeninių daiktų paminètinos rožinio liekanos, žalvarinès grandinèlès su kryželio formos 
pakabučiais. Aptikta keletas monetų, tarp jų - dvi auksinès prancūziškos 1 luidoro ir viena 2 luidorų nominalo moneta (paaiškejo, kad viena 1 luidoro nominalo moneta yra labai kokybiškas falsifikatas). Taip pat rasta Prūsijos ir Rusijos monetų. Iš ginkluotès fragmentų paminètinas titnaginis skiltuvas, pistoletui valyti skirta žalvarinè adata su grandinèle, dalis švininès kulkos ${ }^{87}$. Antropologinių tyrimų metu nustatyta, kad greta vyrų, kurie sudare absoliučią daugumą palaidotųjų, buvo identifikuoti ir keliasdešimties moterų palaikai. Daugiau nei pusè palaidotųjų buvo jauni (nuo 20 iki 30 metų). Pastebèta traumų pėdsakų. Traumos buvo suskirstytos ị tris grupes: sugijusios, begyjančios ir perimortalinès. Daugiausia užfiksuota perimortalinių traumų (ịvykusių prieš pat mirtị, mirties metu arba po mirties, pvz., lūžių, atsiradusių lavonus šiurkščiai renkat iš gatvių, transportuojant, metant ị duobę). Fiksuota ir sugijusių arba pradèjusių gyti kovinių traumų (pvz., galimai dèl smūgių durtuvais atsiradusių šlaunikaulių sužalojimų), pèstininkams būdingų padikaulių lūžių ${ }^{88}$.

V. Pugačiauskas surinko istorinę medžiagą, kuria remiantis galima tiksliau sužinoti kapavietės atsiradimo aplinkybes. Ši kapavietė įrengta $1813 \mathrm{~m}$. apie $3 \mathrm{~km}$ nuo tuomečio miesto centro, neapgyvendintoje laukymejje, dešiniajame Neries krante, kur Napoleono kariuomenès kariai $1812 \mathrm{~m}$. buvo įrengę lauko ịtvirtinimus. Dalis šių ịtvirtinimu vèliau, Rusijos kariuomenés padaliniams ir miesto administracijai išvežant mirusių Napoleono kariuomenès karių lavonus, tapo masinès kapavietės vieta. Remiantis išlikusiais šaltiniais galima teigti, kad palaidota kapavieteje buvo apie 7190 karių. Čia taip pat buvo užkasti ir 112 arklių lavonai. Kariai mirè daugiausia ne dèl kovinių sužalojimų, o dèl fizinio išsekimo, šalčio, bado ir ligų (pvz., dèmètosios šiltinès). Moterų laidojimas kartu su vyrais aiškintinas tuo, kad Napoleono armijos žygiuose dalyvaudavo ir markitančių. Pagal kapavietèje rastas sagas (jų aptikta apie tris tūkstančius) pavyko nustatyti nemažai Napoleono pulkų, kurių kariai yra palai-

87 Poškienė J. Masinès Napoleono armijos karių kapavietės Vilniuje, Šiaurès miestelyje, Verkių g. (dab. S. Žukausko g.), 2002 m. LIIR, f. 1, b.3975; Poškienė J. Napoleono Didžiosios armijos karių masinès kapavietès tyrinejjimai Vilniuje // Archeologiniai tyrinèjimai Lietuvoje 2002 metais. Vilnius, 2005, p. 220-222.

88 Jankauskas R. Masinès kapavietės Verkių g. antropologinių tyrimų ataskaita. Idètiniai lapai ataskaitoje: Poškienė J. Masinės Napoleono armijos karių kapavietės Vilniuje, Šiaurès miestelyje, Verkių g. (dab. S. Žukausko g.), 2002 m. LIIR, f. 1, b.3975, p. 13-22. 
doti šioje kapavietejje ${ }^{89}$.

Ištirti žuvusių Napoleono kariuomenès karių palaikai buvo iškilmingai perlaidoti bendrame kape Antakalnio kapinèse.

\section{UŽUPIS}

\subsection{Polocko g. ir Kreivojo skg. sankirta}

Antrojo pasaulinio karo laikotarpio (?) kapas XVII a. kapinyno teritorijoje. $1999 \mathrm{~m}$. archeologas Linas Girlevičius atliko tyrimus Polocko gatvès ir Kreivojo skersgatvio sankirtoje, kur rastas XIX-XX a. kultūrinis sluoksnis, pavienių XVIII a. radinių ir aptiktas XVII a. kapinynas. Jame buvo ištirti 22 kapai su 28 visiškai išlikusiais arba apardytais palaikais ${ }^{90}$. Iš bendro konteksto išsiskyrè kapas Nr. 12, galimai datuotinas XX a. Šiame smarkiai apardytame kape, kuriame išlikę tik kojų kaulai, šalia jų buvo rasta brezento likučiais aplipusių pistoleto šovinių ${ }^{91}$. Atlikus palaikų antropologinę analizę konstatuota, kad kape palaidotas vyresnis nei 20 metų vyras (? $)^{92}$. Gali būti, kad šiame kape palaidotas Antrojo pasaulinio karo metais žuvęs asmuo, tačiau taip pat neatmestina versija, jog pistoleto šoviniai, suvynioti ị brezentą, paprasčiausiai užkasti kapinyno teritorijoje $\mathrm{XX}$ a. ir su pačiu kapu neturi nieko bendra.

89 Pugačiauskas V. Napoleono Didžiosios armijos karių kapavietès 2002 m. rugsejjo tyrimai (istorinė apžvalga). İėtiniai lapai ataskaitoje: Poškienė J. Masinès Napoleono armijos karių kapavietės Vilniuje, Šiaurès miestelyje, Verkių g. (dab. S. Žukausko g.), 2002 m. LIIR, f. 1, b. 3975, p.8-12.

90 Girlevičius L. Tyrinèjimai Vilniuje, Polocko g. - Kreivojo skg. sankirtoje, 1999 m. // Archeologiniai tyrinejimai Lietuvoje 1998 ir 1999 metais. Vilnius, 2000, p. 428-429.

91 Girlevičius L. Archeologiniai tyrimai Vilniuje, prie Polocko gatvès - Kreivojo skersgatvio sankirtos, 1999 metais. LIIR, f. 1, b. 3360, p. 24-25, 30.

92 Jankauskas R. Archeologinių tyrinèjimų 1999 m. Vilniuje, Polocko g. / Kreivasis skg., kaulinès medžiagos antropologinès analizès rezultatai. Idètiniai lapai ataskaitoje: Girlevičius L. Archeologiniai tyrimai Vilniuje, prie Polocko gatvès - Kreivojo skersgatvio sankirtos, 1999 metais. LIIR, f. 1, b. 3360, p. 91-94. 


\section{RASOS}

\subsection{Naujųjų Rasų kapinės}

Antrojo pasaulinio karo SSRS karių ir kitų asmenų kapavietė. 2005 m. archeologas Robertas Žukovskis Lietuvos gyventojų genocido ir rezistencijos tyrimo centro (LGGRTC) užsakymu atliko tyrimus (ištyrẻ dvi perkasas, iš viso - $16,4 \mathrm{~m}^{2}$ plotą) Naujųjų Rasų kapinių pietrytiniame pakraštyje, krūmais ir aukšta žole apaugusiame šlaite. LGGRTC buvo gavusi informacijos iš šalia kapinių jau daugelị metų gyvenančio A. J. Kozičiaus (g. 1939 m.), kad šioje vietoje 1945-1948 m. uniformuoti asmenys sunkvežimiais ir vežimais atvažiuodavę ir laidodavę žmonių lavonus. Spèta, kad šioje kapinių teritorijoje būta masinių Antrojo pasaulinio karo ir pokario laikų kapų. Vienoje iš tirtų perkasų (Nr. 2) rasti du masiniai kapai. Kape Nr. I, kurio duobès gylis siekè 2,4 metro, mirusieji suguldyti vienu metu net šešiais sluoksniais. Rasti septynių vyrų (amžius - nuo 20 ik 50 metų; bendras palaidotųjų vyrų amžiaus vidurkis - daugmaž 32 metai) palaikai. Daugelis vyrų i kapo duobę buvo paguldyti ant nugaros ir tik vienas - ant

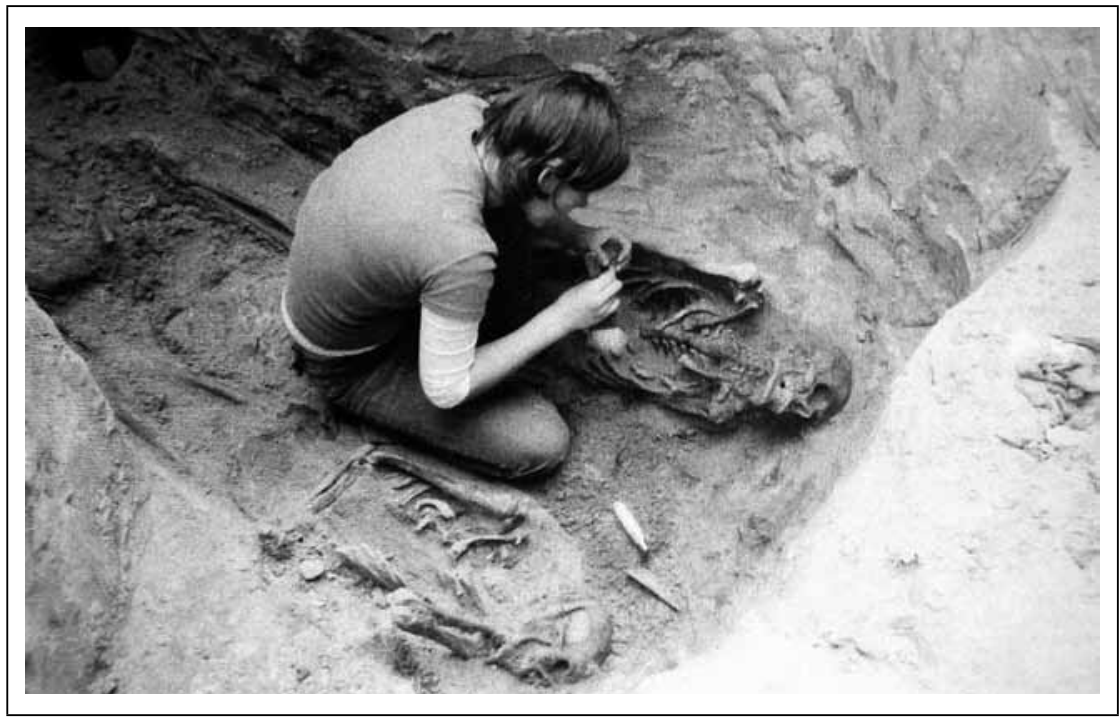

10 pav. Archeologiniai tyrimai Naujųų Rasų kapinių pietrytinejje dalyje.

Žukovskis R. Žvalgomuju archeologiniu tyrimu Naujujų Rasu kapiniu teritorijoje, Vilniuje, 2005 metais ataskaita. Vilnius, LIIA, f. 1, b. 3718 
pilvo. Akivaizdu, kad šiame kape rasti palaidoti sovietinès kariuomenės kariai. Tai liudija šalia daugelio mirusiųjų griaučių aptiktos vienodos aprangos detalès (sagos, dalis kurių yra su penkiakampėmis žvaigždėmis, kai kurios puoštos pjautuvu ir kūju; vienodos diržų sagtys), kaklo srityje rasti geležiniai kabliukai su kilpelèmis (uniforminès aprangos apykaklei susegti) ir kt. ${ }^{93}$ Ir tyrimų autorius R. Žukovskis ${ }^{94}$, ir antropologinę šios masinès kapavietès medžiagą tyrę R. Jankauskas, A. Barkus ir A. Urbanavičius ${ }^{95}$ prièjo bendrą išvadą, kad nè viename skelete nerasta jokių traumų pėdsakų, leidžiančių ịtarti smurtinę mirties priežastị. Iškelta versija, kad mirusieji yra Raudonosios armijos kariai, veikiausiai karo belaisviai, mirę nuo bado ir ligų ir palaidoti vienu metu ${ }^{96}$. Tiesa, dèl kai kurių radinių negalima visiškai atmesti ir kai kurių iš šių žmonių sušaudymo tikimybės. Štai sluoksnyje Nr. 1 rastuose 40-50 metų vyro palaikuose, krūtinès srityje, rasta kulka ${ }^{97}$. Ar tikrai ji nebuvo šio žmogaus mirties priežastis? Sluoksnyje II aptiktuose palaikuose „B“, priklausančiuose 25-30 metų vyrui, krūtinès srityje rastas „švininis šratas“ (?) $)^{98}$. Ar jis taip pat nebus susijęs su šio vyro mirties priežastimi? Perkasoje Nr. 2 buvo rasta antra masinė kapavietė. Jos tyrimų metu paaiškejjo, kad šioje taip pat 2,4 m gylio duobeje būta kitos masinès kapavietès. Joje rasti dar 6 žmonių ( 4 moterų ir 2 vyrų) palaikai.

Akivaizdu, kad bent dalis grupinejje kapavietėje palaidotų asmenų buvo SSRS kariuomenès kariai. Kitų asmenų tapatybė iki šiol lieka mįslè.

\subsection{Dunojaus g. 27}

Antrojo pasaulinio karo Vokietijos karių kapavietė. 2004 m. Všt Kultūros vertybių globos tarnyba, gavusi informacijos iš gyventojų apie

93 Žukovskis R. Žvalgomųjų archeologinių tyrimų Naujųjų Rasų kapinių teritorijoje, Vilniuje, 2005 metais ataskaita. Vilnius, LIIA, f. 1, b. 3718, p. 8-11.

94 Žukovskis R. Žvalgomieji archeologiniai tyrimai Vilniuje, Naujųjų Rasų teritorijoje // Archeologiniai tyrinejimai Lietuvoje 2005 metais. Vilnius, 2006 m., p. 138-141.

95 Jankauskas R., Barkus A., Urbanavičius A. Preliminarūs 2005 m. kasinèjimų antropologinès medžiagos tyrimų rezultatai // // Archeologiniai tyrinejjimai Lietuvoje 2005 metais. Vilnius, 2006 m., p. 434-455.

96 Žukovskis R. Žvalgomieji archeologiniai tyrimai Vilniuje, Naujųų Rasų teritorijoje // Archeologiniai tyrinejjimai Lietuvoje 2005 metais. Vilnius, 2006 m., p. 139.

97 Ten pat, p 139.

98 Ten pat, p 139. 
privačiame sklype Dunojaus g. 27 esančią Antrojo pasaulinio karo vokiečių karių kapavietę, kartu su Vokiečių karių kapu globos tautinès sąjungos ekshumuotojų grupès Lietuvoje atstovais atliko 11 vokiečių karių palaikų ekshumaciją. Vietos gyventojos A. Bončkovskajos liudijimu, karo pabaigoje jos tèvas palaidojo žuvusius vokiečių karius aviacinės bombos išmuštoje duobejje. Prieš palaidodamas žuvusiuosius, jis esą paėmė vertingesnius daiktus (taip pat ir kario identifikavimo žetonus) ir perdavè juos Raudonojo Kryžiaus organizacijos atstovams. Ekshumacijos metu greta palaikų rastas vienas identifikavimo žetonas ir auksinis vestuvinis žiedas. Palaikai buvo perlaidoti vokiečių karių kapinèse Vingio parke ${ }^{99}$.

\section{LIEPKALNIS}

\section{1. Žirnių g.}

Antrojo pasaulinio karo Vokietijos karių kapavietè. 2012 m. birželio $4 \mathrm{~d}$. Žirnių gatveje, IKEA prekybos centro statybos vietoje, griaunat senų metalinių garažų kompleksą, buvo aptikti nuo penkių iki septynių vokiečių karių (manoma, parašiutininkų) palaikai. İdomi aplinkybè: panašu, kad visi žuvę kariai buvo palaidoti stati ${ }^{100}$. Greta rasta aprangos ir amunicijos detalių, karių identifikavimo žetonai, šalmai ant kaukolių, šešios 1939 m. pagamintos granatos. Granatas ir šovinius sunaikino Juozo Vitkaus inžinerijos bataliono išminuotojai. Kultūros paveldo departamento vyriausioji valstybinè inspektore Audronẻ Vyšniauskienė žiniasklaidai teigé, kad palaikai bus perlaidoti vokiečių karių kapinėse Vingio parke ${ }^{101}$. Kultūros paveldo departamento Vilniaus teritorinis padalinys perdavė Všt Kultūros vertybių globos tarnybai kai kuriuos kapavieteje

99 Volksbund Deutsche Kriegsgräberfürsorge e.V. Umbettungsbericht. Dunojaus g-ve, Vilnius, 17.05.-18.05.2004. Vergebene U-Nr.: 006-016 (Všt Kultūros vertybiu globos tarnybos archyvas).

${ }^{100}$ Seną garažų masyvą Vilniuje griaunantys darbininkai aptiko šešių žuvusių kareivių palaikus. Interneto prieiga: http://www.15min.lt/naujiena/ziniosgyvai/istorija/sena-garazu-masyva-vilniuje-griaunantys-darbininkai-aptiko-sesiu-zuvusiu-kareiviu-palaikus-582-22378 [tikrinta 2012-11-16]

${ }^{101}$ Vilniuje aptikti vokiečių parašiutininkų palaikai. Interneto prieiga: http://www.alfa.lt/ straipsnis/14715174/Vilniuje.aptikti.vokieciu.parasiutininku.palaikai=2012-06-04_15-40/ [tikrinta 2012-11-16] 
aptiktus radinius: identifikavimo žetoną, odinių diržų fragmentus, gertuvę, šautuvo dalį ir kt. ${ }^{102}$ Sprendžiant iš radinių ir palaikų padèties radimvieteje, kariai čia veikiausiai ne palaidoti kape, o žemėmis užversti tranšejoje, šalimais sprogus artilerijos sviediniui ar aviacinei bombai. Istoriko Sakalo Natkevičiaus duomenimis, palaikai buvo surinkti ir perduoti Teismo medicinos instituto ekspertams. Rengiant ši straipsni jokių išvadų dèl karių žūties priežasčių ir patirtų traumų dar nebuvo parengta ${ }^{103}$. Yra žinoma, kad $1944 \mathrm{~m}$. liepos 7 d. vakare i Vokietijos kariuomenès nuo bandančių užimti miestą SSRS pajègų ginamą Vilnių lèktuvais Ju-52 buvo atskraidinti ir oro uoste Kirtimuose išlaipinti apie 200 Vermachto 16-ojo parašiutininkų pulko (FJR 16 - Fallschirmjäger Regiment 16) 2-ojo bataliono karių ${ }^{104} .1944 \mathrm{~m}$. liepos 8 d. ryte juos sutriuškino veikiausiai Raudonosios armijos 29-ojo tankų korpuso 25-oji tankų brigada ${ }^{105}$. Veikausiai Žirnių gatveje statybų metu buvo aptikti žuvusių 16-ojo parašiutininkų pulko karių palaikai.

\section{NAUJININKAI}

\subsection{Tyzenhauzu g. 18A}

Spėjama 1812 m. karo Napoleono karių kapavietė. 1992 m. archeologas E. Skardžius atliko archeologinius tyrimus Tyzenhauzų g. 18A, šalia Vilniaus gimdymo namų. Tyrimų metu rasta grupinių kapų. Deja, archeologas neparengè tyrimų ataskaitos, tik perdavè radinius Lietuvos nacionaliniam muziejui. Todèl žinoma tik dalis tyrimų rezultatų. Neaiškus nei palaidotų asmenų skaičius, nei tikslesnis palaidojimo pobūdis (tik muziejui perduodamo radinių sąrašo pradžioje užsiminta apie grupinius „palaidojimus“). Tyrimų metu buvo rasta žalvarinių ir kaulinių sagų, dirbinio iš žalvarinès vielos žiedelių fragmentas, trys žalvarinės plokštelès,

\footnotetext{
102 Perdavimo-prièmimo aktas. 2012 m. birželio 13 d. Nr. 1 (Všt Kultūros vertybiu globos tarnybos archyvas).

${ }^{103}$ S. Natkevičiaus žodinè informacija (2012 m. lapkričio 22 d.).

${ }^{104}$ Ittvirtinto Vilniaus rajono komendanto gen. Gerhardo Poelio raportas. U.S. National Archives and Records Administration (NARA), T. 313, Roll 319, fr. 8597961-8597964.

105 Центральный архив Министерства обороны РФ (ЦАМО), ф. 29 ТК, оп. 1, д. 14, л. 165.
} 


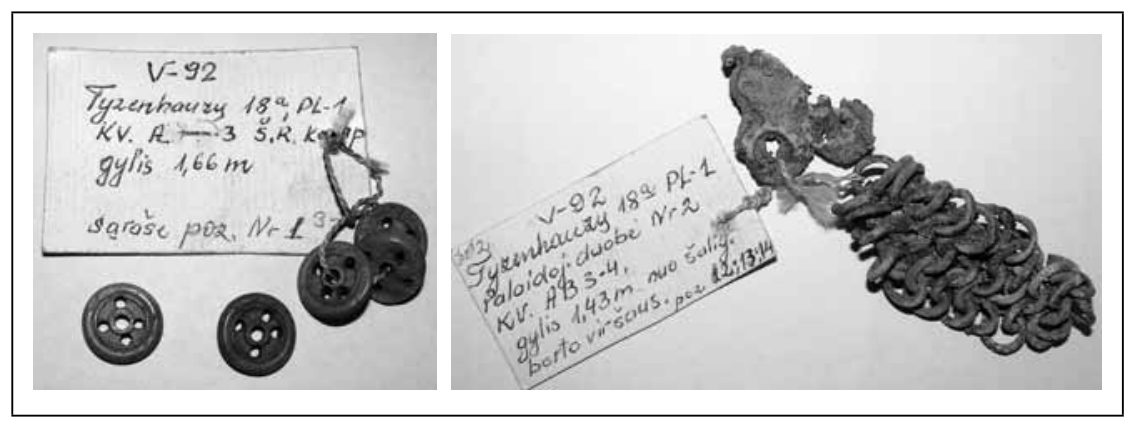

11-12 pav. Radiniai iš spejamos 1812 m. Napoleono armijos karių kapavietès, $1992 \mathrm{~m}$. tirtos Tyzenhauzų g. 18A. M. Vitkūno nuotraukos, $2012 \mathrm{~m}$.

žalvarinis diržo sagties liežuvèlis, geležinė bato kulno pasagèlè, vilnonès kepurès ir milinès (?) apykaklès fragmentų ${ }^{106}$. Apžiūrëjus radinius Lietuvos nacionaliniame muziejuje, galima konstatuoti, kad radiniai būdingi XIX a. Tikètina, kad Naujininkuose rasta masinè (?) kapavietė gali būti priskirta $1812 \mathrm{~m}$. karo aukoms. Šioje vietoje ateityje būtų tikslinga atlikti papildomus archeologinius tyrimus.

\section{PANERIAI}

\section{1. Ūmẻdžių g. 16}

$1812 \mathrm{~m}$. Napoleono kariuomenès karių arba $1831 \mathrm{~m}$. sukilimo dalyvių kapavietè. $1998 \mathrm{~m}$. buvo atliekami archeologiniai tyrimai (vadovas - Gintautas Zabiela) Žemuosiuose Paneriuose, Ūmèdžių g. 16. Ištyrus $11,5 \mathrm{~m}^{2}$ plotą (dvi perkasas), surinkti ne mažiau kaip 16 asmenų palaikų fragmentai. Kapus buvo labai apardę vietos gyventojai, ịsirengę sklype daržą ir statę šiltnamị. Buvo rasta geležinė diržo sagtis, žalvarinių lystelių, kelios žalvarinès sagos, audinio fragmentų. Surinkti žmonių kaulai ${ }^{107}$. Atlikus palaikų antropologinę analizę paaiškejjo, kad surinkti

\footnotetext{
${ }^{106}$ Skardžius E. Vilniaus m. gimdymo namų ginekologinis korpusas Tyzenhauzų 18A žv. archeologinių tyrimų plotas už PR fasado šalia $1992 \mathrm{~m}$. iškastos tranšèjos lietaus kanalizacijai. Lietuvos nacionalinio muziejaus Viduramžių ir naujųjų laikų archeologijos skyriaus archyvas, b. 22, p. 1-4.

${ }^{107}$ Zabiela G. Žemụjų Panerių (Vilnius, Ūmèdžių g. 16) žmonių kaulų radimvietès 1998 m. archeologinių tyrinejjimų ataskaita. LII R, f. 1, b. 3090, p. 3-5.
} 
ne mažiau kaip 16 vyrų palaikų fragmentai. Mirusiųjų amžius - ne daugiau kaip 40 metų, o kai kurie nebuvo sulaukę ir 20-ies. Traumų pèdsakų kauluose nepastabèta. Palaikų amžiaus ir lyties rodikliai leidžia manyti, kad čia būta masinès kapavietés, o joje palaidoti kariai ${ }^{108}$. G. Zabiela iškèlè dvi versijas, kas galëjo būti palaidoti šioje kapavieteje: arba $1812 \mathrm{~m}$. gruodị iš Vilniaus besitraukiantys Napoleono kariuomenès kariai, mirę nuo šalčio ir veikiausiai $1813 \mathrm{~m}$. pavasari palaidoti šioje vietoje, arba $1831 \mathrm{~m}$. birželio $19 \mathrm{~d}$. Panerių kautynėse žuvę sukileliai. Tąsyk kautynèse žuvo apie 600 sukilèlių, jie buvo palaidoti Paneriuose. Tiksliau atsakyti $\mathfrak{x}$ šį sudètingą klausimą padètụ bent kiek išraiškingesnès aprangos detalès, tačiau kapavieteje rastos sagos buvo be piešinių. Tik konstatuota, kad sagos gali būti angliškos ir datuotinos XIX a. pirmąja puse. Taigi, nè viena versija nebuvo iki galo nei patvirtinta, nei paneigta. Tyrimų vadovas padare išvadą, kad, sprendžiant iš surinktų radinių, antropologinių tyrimų rezultatụ ir laidojimo pobūdžio, šioje vietoje greičiausiai buvo užkasti $1812 \mathrm{~m}$. pabaigoje mirtinai sušalusių Napoleono kariuomenès karių palaikai ${ }^{109}$.

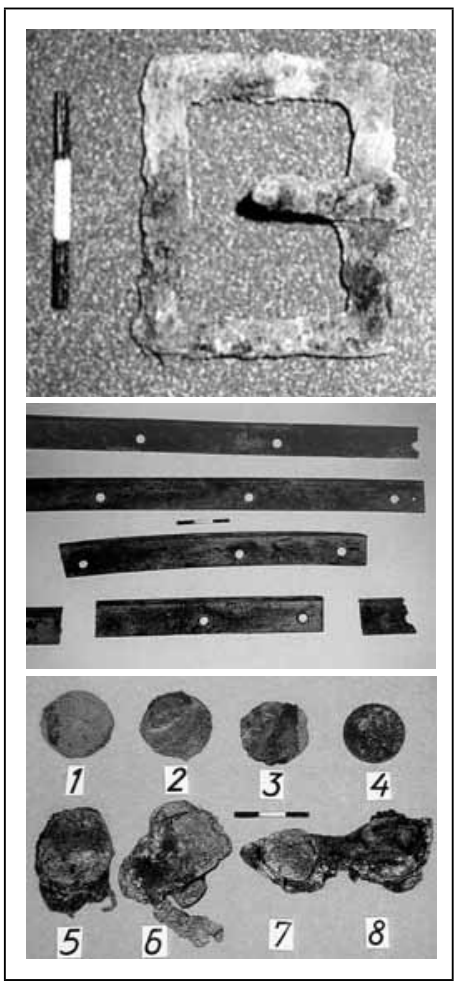

13-15 pav. Radiniai, aptikti tiriant Napoleono armijos karių arba $1831 \mathrm{~m}$. sukilimo dalyvių kapavietę Paneriuose, Ūmèdžių g. 16. Zabiela G. Žemuju Panerių (Vilnius, Ūmèdžiu g. 16) žmoniu

kaulu radimvietes $1998 \mathrm{~m}$. archeologiniu tyrinejimu ataskaita. LII R, f. 1, b. 3090

\footnotetext{
${ }^{108}$ Jankauskas R. Palaikų iš Žemųjų Panerių (Vilniaus), rastų 1998 m. gegužès mèn., antropologinio tyrimo ataskaita. Ídetinis lapas ataskaitoje: Zabiela G. Žemųjų Panerių (Vilnius, Ūmèdžių g. 16) žmonių kaulų radimvietės 1998 m. archeologinių tyrinèjimų ataskaita. LII R, f. 1, b. 3090, p. 6.

${ }^{109}$ Zabiela G. Žemụjų Panerių (Vilnius, Ūmèdžių g. 16) žmonių kaulų radimvietès 1998 m. archeologinių tyrinejjimų ataskaita. LII R, f. 1, b. 3090, p. 7-8.
} 


\section{BAIGIAMOSIOS PASTABOS}

Sudarius iki šiol Vilniaus mieste archeologinių tyrimų metu rastų karių kapaviečių sąvadą tapo akivaizdu, kad žinios apie karių kapus Vilniaus mieste iki šiol buvo nesusistemintos, todèl tik nedidelè jų dalis pateko ị istorikų (taip pat ir karo istorikų) akiratị. Dauguma informacijos neskelbta ir saugoma tik archeologinių tyrimų ataskaitų forma. Kai kurių tyrimų duomenys yra nepakankamai dokumentuoti arba išvis nedokumentuoti.

Karių kapų ekshumacijų duomenys dar laukia tyrëjų. Labai svarbu ne tik tinkamai fiksuoti informaciją apie anksčiau atliktas ir mūsų dienomis vykdomas ekshumacijas ir karių palaikų perlaidojimą, bet ir ieškoti pamirštų ịvairių kariuomenių karių palaidojimo vietų, jas deramai iamžinti.

Karių kapaviečiu tyrimų duomenys yra gana informatyvūs ir gali padèti atskleisti kai kuriuos Vilniaus miesto ir Lietuvos karo istorijos puslapius.

Neabejotina, kad šis sąvadas ateityje bus papildytas naujų archeologinių tyrimų ir ekshumacijų duomenimis. 


\title{
TOMBES DES SOLDATS À VILNIUS, TROUVÉS LORS DES EXPLORATIONS ARCHÉOLOGIQUES
}

\author{
Dr. Kęstutis KATALYNAS \\ Musée nationale de Lituanie \\ Dr. Manvydas VITKŪNAS \\ Académie de guerre du Général Jonas Žemaitis de Lituanie
}

La capitale de Lituanie Vilnius est devenue quelque fois l'arène des luttes. Dans la deuxième partie du XIVème siècle la ville était attaquée quelque fois par l'ordre des allemands et ses coalisés. En 1655 la capitale de Lituanie était occupée la première fois par l'armée de pays étrangère, et donc jusqu’à des années 1661 son patron étaient les russes. Pendant que dans les années 1702, Vilnius était occupé par l’armée de la Suède. Les batailles des rebelles combattant pour la liberté de Lituanie et de la Pologne contre les unités de l'armée russe se déroulaient à Vilnius en 1794, et aux environs de Vilnius en 1831. Dans les années 1812 Vilnius devenait l'une des bases principales de la Grande armée du Napoléon lors de l'intrusion dans l'empire de la Russe. Au surplus, dans les années 1863-1864 les exécutions des participants de la révolte étaient faites à Vilnius aussi. Lors des années de la Première guerre mondiale, l'armée de l'Allemagne est occupée la ville de Vilnius sans aucun combat. Dans la période des années 1918-1920 Vilnius passait plusieurs de fois de la main à la main - son patron était les forces de Lituanie, des bolchéviques et des polonais, beaucoup de luttes se sont passées dans la ville et surtout à ses environs. Toutefois, en 1939 Vilnius a rentré dans la juridiction de Lituanie, mais en 1940 les unités de l'armé occupante de l'Union Soviétique se sont y installées. Lors des années de la Deuxième guerre mondiale Vilnius était délabré assez terriblement, puisque les batailles se sont passées juste dans ses rues.

Il y a déjà plusieurs d'années que des explorations archéologiques sont observées dans la ville de Vilnius, en plus des ensevelissements des soldats particuliers ou de ces groupes inconnus étaient trouvées et parfois - des cimetières massives. Larticle présente aussi le corpus 
réglementaire des tombes des soldats trouvés à Vilnius lors des explorations archéologiques. Les cimetières y inscrites sont celles où les personnes enterrées étaient considérées comme péries ou des soldats morts à cause des autres raisons, et même la manière d'enterrement (des tombes particulières trouvées dans les endroits inhabituels, des cimetières non typiques différant du contexte générale des cimetières dans la ville, où la plupart des gens enterrées sont des hommes ou presque des hommes), en plus les artefacts étaient trouvées aussi dans les cimetières (l'habillement des soldats, détails des tenues militaires, armes), lors des recherches anthropologiques des lésions (abattues, tirées) causées par des batailles remarquées sur les os permettent de supposer que des personnes enterrées étaient les soldats.

Le corpus réglementaire présente des tombes datées au milieu du XVIIème siècle - milieu du XXème siècle. Il n'existe pas encore des données trouvées lors des explorations archéologiques concernant les ensevelissements de la période ancienne qui pourraient être qualifiées comme les tombes des soldats.

Par ailleurs, le corpus réglementaire ne présente pas de l'endroit d'enterrement exclusif qui était exploré par les archéologues - c'est le cimetière des victimes des structures répressives soviétiques dans le domaine de Tuskulènai où les personnes tuées dans la prison d'intérieur du Commissariat du Peuple de sûreté de l'Etat (Ministère de la sécurité de l'État) étaient mises en terre dans le secret.

Des tombes des soldats probables de l'armée occupante de Russie résidaient dans la capitale de Grand-duché de Lituanie à Vilnius dans les années 1655-1661 ont été trouvées dans le territoire du château bas de la ville de Vilnius. Néanmoins certains chercheurs estiment que dans un des tombes les participants de la révolte contre l'empire de Russe en 1863-1864 au lieu des soldats russes. En outre, le cimetière massif dans le territoire du parc des Montagnes est attaché avec des événements des années 1655-1661.

Le cimetière massif des soldats de l'armée du Napoléon qui était en train de reculer à l'Ouest vers Vilnius à la fin des années 1812 est vraiment exclusif où au moins 2724 personnes étaient enterrées. De plus, deux cimetières probables des soldats du Napoléon étaient encore trouvés dans la ville. 
Dans la lisière occidentale de la ville, à Paneriai, le cimetière est trouvé où les participants de la révolte en 1831 ou les campagnes militaires en 1812 sont enterrées. En outre, lors des explorations archéologiques dans les deux ou trois endroits du centre-ville de Vilnius, les cimetières massifs des soldats de l'empire de Russie disloquée dans la ville au XIXème siècle, sont trouvés.

Dans les différents endroits de Vilnius, les cimetières des soldats de l'armée de l'Union Soviétique ainsi que de l'Allemagne de la période de Deuxième guerre mondiale sont trouvés aussi. Des batailles intensives ont déroulé à Vilnius en été de 1944.

Il est indiscutable que dans l'avenir ce corpus réglementaire sera supplée par les données d'exhumation ou reçus lors des nouvelles explorations archéologiques. 


\title{
SOLDIERS' GRAVES IN VILNIUS FOUND DURING ARCHEOLOGICAL EXPLORATIONS
}

\author{
Dr. Kęstutis KATALYNAS, \\ National Museum of Lithuania \\ Dr. Manvydas VITKŪNAS, \\ The General Jonas Žemaitis Military Academy of Lithuania
}

Lithuanian capital Vilnius became fighting arena not even once. During the second part of 14th century the city was attacked by German order and its associates several times. In a year 1655, Lithuanian capital was occupied by the army of foreign country for the first time, up until the year 1661 Russians were staying there. In the year 1702, Vilnius was occupied by the Swedish army. In 1794, in Vilnius and, in 1831, in its grounds, battles of the rebels fighting with units of Russian army for the freedom of Lithuania and Poland were held. In the year 1812, Vilnius became one of the most important bases of Napoleon's Great Army during his invasion to the Russian empire. During 1863-1864, in Vilnius, executions were made for the participants of mutiny taking place at that time. During the years of World War I, German army occupied Vilnius without any battle. In the years 1918-1920, Vilnius went from one hand to another several times, it was owned by the forces of Lithuania, Bolsheviks, Poland; in the city and especially in its grounds, battles were taking place. In the year 1939, Vilnius came back to jurisdiction of the state of Lithuania, but just in 1940 occupational army units of Soviet Union established in it. During the years of World War II, Vilnius was destructed quite badly; many battles were taking place in its streets.

By implementing archaeological explorations in Vilnius city for many years, entombments of single soldiers or their groups, sometimes even massive graves are found, which were not known before. In this article digest of soldiers' graves found during archaeological explorations in Vilnius is provided. It includes such gravesites in which the people being buried are considered to be killed or soldiers that were dead for various 
other reasons, and the way of burial itself (separate graves found in places that are not common for burial, non-typical gravesites that go out of the common city cemetery context, in which only men or almost only men are buried), artefacts found in gravesite (details of soldiers' clothing, uniform, guns) during the anthropological analysis, injuries of tactical nature (traverse, gunshot) found in the bones, confirm the consideration of treating buried persons as soldiers.

Graves reviewed in the digest are dated from the middle of 17 th century to the middle of 20th century. Data about entombments of earlier period, which could be definitely said to be of soldiers are not given by recent archaeological explorations.

In this digest, the exceptional burial place researched by archaeologists is not reviewed, which is the gravesite of Soviet repressive structure victims in Tuskulenai manor, where during the year 1944-1947 persons killed in inner jail of NKGB (MGB) were secretly buried.

During the year 1655-1661 in the capital Vilnius of Great Duchy of Lithuania, supposedly found graves of soldiers of former occupational Russian army were found in the territory of the Lower castle of Vilnius. However, some of the researchers think that in one of those gravesites, there are no Russian soldiers buried, but participants of mutiny of 1863-1864 against Russian empire. Massive gravesite in the territory of Park of Hills is related to the incidents of the year 1655-1661.

Exceptional one is massive gravesite of Napoleon's army, which was retreating through Vilnius to the west, at the end of 1812, in that gravesite no less than 2724 persons were buried. Two more gravesites that supposedly are of Napoleon's soldiers were also found in the city.

In the western corner of the city, Paneriai, gravesite was found in which participants of 1812 military campaign or participants of the mutiny of the year 1831 are buried. During the archaeological explorations, in two or three places of central part of Vilnius, massive gravesites were found of soldiers of Russian empire army, which were situated in the city in 19th century.

In various places of Vilnius, gravesites of soldiers were found from armies of Germany and USSR from the period of World War II. In the summer of 1944, intensive battles were taking place in Vilnius.

It is certain that in the future this digest will be supplemented with new data of archaeological researches and exhumations. 